\title{
A Revolução Copernicana: aspectos históricos e epistemológicos
}

The Copernican Revolution: historical and epistemological aspects

\author{
Claudio Maia Porto*1]
}

${ }^{1}$ Universidade Federal Rural do Rio de Janeiro, Departamento de Física, Seropédica, RJ, Brasil

Recebido em 30 de julho de 2019. Revisado em 25 de dezembro de 2019. Aceito em 27 de dezembro de 2019

\begin{abstract}
Neste trabalho fazemos uma apresentação didática da chamada Revolução Copernicana, destacando alguns aspectos históricos e epistemológicos a ela associados. Procuramos, em especial, mostrar como a história da ciência astronômica, na qual está inserida o modelo heliocêntrico de Copérnico, esteve sempre sujeita a uma disputa entre duas concepções científicas, que poderíamos chamar de realismo e de instrumentalismo, sobretudo no que se refere ao emprego por Ptolomeu de dispositivos como o equanto e o excêntrico na descrição dos movimentos planetários. Fazemos uma breve exposição do pensamento cosmológico de Aristóteles e dos modelos astronômicos geocêntricos de Ptolomeu e seus sucessores árabes e, então, uma exposição mais detalhada, ainda que qualitativa, da nova proposta de Copérnico, bem como de seus fundamentos epistemológicos. Por último, procuramos mostrar também como essa proposta, em princípio restrita a um campo de saber específico, abalou completamente a concepção científica e filosófica aristotélica então amplamente prevalecente, constituindo mais um elemento de confronto entre uma nova visão de mundo emergente e outra, já em seus derradeiros momentos, conflito que se refletiu de maneira acentuada no domínio religioso.
\end{abstract}

Palavras-chave: História da Física, Astronomia, Revolução Copernicana, Realismo Científico e Instrumentalismo.

In this paper we make a didactic presentation of the so-called Copernican Revolution, highlighting some historical and epistemological aspects associated with it. In particular, we seek to show how the history of astronomical science, in which Copernicus' heliocentric model is inserted, has always been subject to a dispute between two scientific conceptions, which we might call realism and instrumentalism, especially as regards Ptolemy's use of devices such as the equant and eccentric in describing planetary motions. We give a brief exposition of Aristotle's cosmological thinking and the geocentric astronomical models of Ptolemy and his Arab successors, and then a more detailed, though qualitative, exposition of Copernicus's new proposal as well as its epistemological foundations. Finally, we also seek to show how this proposal, in principle restricted to a specific field of knowledge, completely shook the widely prevailing Aristotelian scientific and philosophical conception, constituting yet another element of confrontation between a new emerging worldview and another, already in its last moments, a conflict that was reflected strongly in the religious domain.

Keywords: History of Physics, Astronomy, Copernican Revolution, Scientific Realism and Instrumentalism.

\section{Introdução}

A Revolução Copernicana constituiu um evento científico culminante na história cultural da humanidade. Seus desdobramentos ultrapassaram em larga medida os limites do campo de saber em que se originou e se irradiaram para as diferentes áreas do pensamento humano, desencadeando uma completa transformação da forma como o homem via o Universo e a si mesmo. Esta transformação promoveu a substituição de uma visão de mundo fundamentada no pensamento aristotélico por outra imagem da Natureza e do Universo, característica da ciência moderna [1] 2] [3] uma ciência que, mais do que reinvidicar bases metodológicas novas e precisas, com o método experimental formulado por Galileu e a matematização de sua linguagem, era portadora de uma

${ }^{*}$ Correspondence email address: claudio@ufrrj.br concepção radicalmente diferente da realidade material. De fato, a ideia da Terra em movimento em torno do Sol trouxe consigo questionamentos fundamentais de ordem física e metafísica. No campo metafísico, como justificar a existência de um mundo terrestre singularizado em sua essência corruptível, como então considerado, em face de uma Terra descentralizada e tornada um planeta como os demais? Por outro lado, o fato de não experimentarmos em nossa vivência efeitos de um possível movimento terrestre levava à necessidade de se construir uma nova física, compatível com essa constatação - melhor dizendo, omissão. Ambas as questões confluíram na construção de um novo paradigma de Universo, infinito, desprovido de qualquer ordenamento prévio e povoado por uma matéria livre de tendências inerentes a sua natureza.

Toda essa mudança paradigmática conduziu a uma grande crise do ponto de vista simbólico e existencial. 
O Universo antigo prestava-se a uma leitura semiótica bastante clara. Em primeiro lugar, seu caráter geocêntrico e sua estrutura metafísica organizada em termos de uma nobreza centrifugamente crescente expressavam maravilhosamente, de maneira analógica e metafórica, o drama da existência humana, tensionada entre os pólos moralmente opostos da materialidade e da espiritualidade [4]. Em vez de uma exaltação da natureza humana em sua centralidade cosmológica, como se pode pensar a princípio, a configuração do Cosmos antigo antes exprimia a proximidade do homem à corruptibilidade do elemento material, sobre o qual vivia, bem como seu distanciamento da nobreza espiritual das dimensões celestes. Esta configuração impregnada de significado foi substituída por um Universo infinito, impessoal e regido por uma causalidade cega, que condenava o homem a uma angústia existencial, fruto do desterro em um mundo destituído de conteúdo simbólico.

Entretanto, assim como ganha em relevo, pelas diversas implicações nos mais diferentes planos da vivência humana, o evento da revolução astronômica também coloca questões muito importantes para sua análise, a maioria das quais permanece sem resposta definitiva. Entre essas questões, salienta-se uma, de caráter muito amplo: quais as virtudes e fragilidades de uma proposta científica dessa natureza, capaz de confrontar e subverter um esquema teórico secularmente consolidado e que trazia a seu lado uma visão de mundo abrangente, apoiada num sistema de saberes e crenças devidamente institucionalizados?

Ao lado de questão tão ampla existem outras que lhe são preliminares ou constituem seu detalhamento.

Com efeito, é um fato amplamente conhecido que Copérnico atribuiu à Terra um movimento planetário e ao Sol um posicionamento central no modelo cosmológico, antes ocupado por nosso planeta. No entanto, algumas importantes questões surgem a respeito do tema, como, por exemplo, qual a dimensão exata da mudança assim formulada? O que teria levado Copérnico a essa proposição? Por que essa proposição surgiu naquele momento histórico? A que problemas ela respondia? Qual a verdadeira natureza das reações que despertou? Algumas dessas perguntas são de mais fácil resposta, outras são ainda

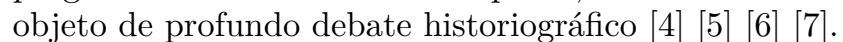

Esclarecemos desde já que nosso objetivo nesse trabalho consiste apenas na apresentação, talvez sob outro olhar, de alguns elementos históricos e epistemológicos ligados ao tema, a maioria dos quais já foram levantados pelos estudiosos da história da ciência e da cultura. Particularmente, nos interessa enfatizar uma tensão epistemológica que acompanha todo o desenvolvimento da ciência astronômica, praticamente desde os seus primórdios, entre uma concepção científica que pretende descrever o mundo tal como ele é na realidade e outra, cujo objetivo primordial é apenas modelar os fenômenos observados, sem, no entanto, sustentar a realidade ontológica das entidades teóricas empregadas nessa descrição. À primeira vertente damos o nome de realismo científico, enquanto à segunda o de instrumentalismo. A tensão entre essas duas concepções atingiu um climax no início da Era Moderna, quando se confrontaram os ímpetos vitais de uma nova ciência nascente e uma visão de mundo tradicionalista, de inspiração filosófica aristotélica. A materialização mais emblemática desse conflito se deu no embate, se assim podemos chamar, entre Galileu e a Inquisição.

Dentro dessa perspectiva, começamos o nosso trabalho por uma brevíssima apresentação das linhas gerais dessas duas (entre outras existentes) concepções científicas identificadas pela epistemologia: o realismo e o instrumentalismo. Ainda que essas terminologias e classificações sejam contemporâneas e os autores que protagonizaram a história, na maioria das vezes, não tenham reivindicado para si tais filiações (seria, na maior parte dos casos, um anacronismo), podemos utilizar esses conceitos para analisar as posições assumidas por eles ao longo do debate que se desenvolveu em torno dos modelos astronômicos. Na realidade, veremos nas seções a seguir que houve uma tensão quase permanente entre essas duas concepções, principalmente no que se refere ao conflito entre a estrutura material do Cosmos aristotélico, com os princípios estético-metafísicos que lhe regiam, e alguns dispositivos empregados pelos astrônomos para descrição dos movimentos planetários, como os excêntricos e, principalmente, os equantos. Veremos que esse conflito forma a espinha dorsal da dialética através da qual se desenvolveram os vários modelos astronômicos, culminando na obra revolucionária de Copérnico.

Para compreender todo esse processo é preciso trazer à luz a essência do pensamento cosmológico de Aristóteles, que formava a base da visão de mundo na qual se desenvolveram os modelos astronômicos de Ptolomeu e seus sucessores e que, no início da Era Moderna, foi suplantada pela Revolução Científica. Apresentamos o caráter geral do Cosmos aristotélico, buscando destacar como os elementos dessa concepção se articulavam entre si, dotando-a de uma imensa coerência, abrangência e organicidade, em grande medida responsáveis pela enorme longevidade daquela doutrina. Este é o tema da seção 3.

Na seção 4, fazemos uma recapitulação da tradição astronômica grega, sintetizada no modelo ptolomaico, enquanto na seção 5 analisamos resumidamente algumas de suas evoluções, desenvolvidas pela astronomia árabe.

Na seção 6, procuramos destacar algumas questões historiográficas proeminentes relacionadas ao surgimento da revolução copernicana, como, por exemplo, suas motivações e as influências que possivelmente atuaram na formulação dessa nova forma de pensamento. Feito isso, na seção 7 fazemos uma apresentação mais detalhada de resto, já realizada em importantes textos existentes em língua portuguesa [8] [9] [10] [11] - de como essa astronomia heliocêntrica de Copérnico explicava qualitativamente, de forma mais natural, algumas das principais questões observacionais da astronomia Mencionamos, no entanto, o fato de que a descrição quantitativa exata dos fenômenos astronômicos requeria a introdução no modelo heliocêntrico de uma complexidade comparável à do sistema ptolomaico.

Em seguida, na seção 8, trouxemos à discussão alguns aspectos epistemológicos relacionados à concepção astronômica de Copérnico. Procuramos destacar como, no entender do próprio Copérnico, o caráter sistêmico 
dessa proposta constituía seu maior mérito e o maior fundamento de sua veracidade.

Por fim, na seção 9, procuramos analisar as repercussões da proposta copernicana. Destacamos as reações do pensamento tradicionalista de base aristotélica e religiosa à nova ciência astronômica. Mostramos como, novamente, a saída para o aparente conflito entre a nova visão científica e esse tradicionalismo filosófico e religioso, foi, em muitos casos, uma interpretação instrumental da nova astronomia. Veremos, finalmente, que esse confronto atingiu seu climax quando Galileu sustentou perante a Inquisição Romana a realidade estrita da configuração do Universo defendida por Copérnico.

\section{O Debate entre Realismo e Instrumentalismo na Ciência}

Podemos, em linhas gerais, caracterizar uma chamada posição realista perante a ciência, mesmo considerando-se as diversas variantes que assume o termo. Nessa concepção, há uma conotação ontológica, traduzida no fato de que se postula a existência de uma realidade independente do conhecimento ou da percepção humana. Há também um pressuposto epistêmico, qual seja, o de que essa realidade é acessível a nossa razão. A ciência visa, pois, a apreensão dessa realidade, descrevendo-a em termos fiéis. As teorias que o fazem com fidelidade são verdadeiras; as restantes falsas. Ademais, sua verdade ou falsidade, na medida em que se reporta a uma realidade completamente objetiva, independe de sua aceitação por parte dos sujeitos.

Um realista (a respeito de dada teoria ou discurso) sustenta que (1) as sentenças daquela teoria são verdadeiras ou falsas, e (2) o que as torna verdadeiras ou falsas é algo externo - quer dizer, não são (em geral) nossos dados dos sentidos, reais ou possiveis, nem a estrutura de nossas mentes, nem nossa linguagem, etc.. [12, p.26].

Bas van Fraassen nos dá a seguinte formulação do realismo científico:

A ciência visa a dar-nos em suas teorias um relato literalmente verdadeiro de como o mundo é, e a aceitação de uma crença científica envolve a crença de que ela é verdadeira $[12$, p.27].

De acordo com Bas van Fraassen, o anti-realismo é a posição segundo a qual o objetivo da ciência pode ser atendido de forma menos exigente: não é necessário que o relato teórico seja verdadeiro, ou seja, a aceitação da teoria não exige a crença de que ela seja verdadeira, mas apenas que a descrição que faz dos fenômenos possui determinadas virtudes, como, por exemplo, adequação empírica e abrangência.

Uma das formas de anti-realismo é a que a epistemologia chama de instrumentalismo. Mais precisamente, Abbagnano nos diz sobre o instrumentalismo:
Na epistemologia contemporânea, o I.[ Instrumentalismo ] aparece como atitude marcadamente anti-realista de descompromisso ontológico, em virtude do qual as entidades não observáveis de que falam o discurso científico não precisam existir, mas apenas permitir que este dê conta adequadamente daquilo de que deve dar conta, ou seja, dos fenômenos observáveis; a teoria em questão não precisa ser verdadeira e não serve para descobrir as características da realidade [13, p.655].

Na verdade, essas correntes epistemológicas apresentam variadas nuances. Entretanto, em linhas gerais, podemos dizer que, para um instrumentalista radical, os entes teóricos que compõem sua descrição científica são apenas ficcões úteis que permitem ao cientista estabelecer relações entre fenômenos observáveis, dotando-o de capacidade preditiva. Em outras palavras, a abordagem tipicamente instrumental não se compromete com a tese de que seus entes teóricos existam, de fato, na realidade, com as características que lhes são atribuídas. Para ela, entidades como, por exemplo, quarks ou gluons, enquadram-se nessa categoria: instrumentos que permitem a descrição apropriada dos fenômenos que observamos

A disputa entre essas concepções foi constante ao longo da história da ciência. Um caso típico se deu em relação à hipótese atômica. Durante a segunda metade do século XIX, uma nova versão do atomismo se desenvolveu consistentemente, apoiada nos resultados obtidos da Química e das formulações teóricas da mecânica estatística de Maxwell e Boltzmann. No entanto, apesar da consistência teórica, a teoria atômica enfrentou fortes oposições no meio científico. Uma das mais enfáticas veio do cientista e filósofo Ernst Mach, que travou com Boltzmann uma firme polêmica sobre a realidade dos átomos. Mach aceitava a hipótese atômica apenas como uma representação matemática, desprovida de caráter realista:

A teoria atômica possui na ciência física uma função que é similar à de certas representações matemáticas auxiliares. É um modelo matemático para a representação dos fatos [14, p.467] (T.A.).

Somente após as experiências conduzidas em 1909 por Jean Perrin, determinando o número de Avogadro por várias formas distintas e respaldando os resultados da teoria browniana de Einstein, grandes críticos da teoria atômica, como Oswald, se renderam às evidências favoráveis a ela. A existência real dos átomos se tornou, então, a concepção predominante na ciência.

\section{A Cosmologia aristotélica}

Pode-se dizer sem grande polêmica que a primeira grande síntese cosmológica de caráter científico da humanidade se deve a Aristóteles.

A primeira coisa que deve ser dita a respeito do pensamento de Aristóteles é que era totalmente integrado 
e internamente coerente. Não se pode, por isso, compreender a ciência aristotélica, e em particular o objeto de nosso interesse mais imediato, a saber, sua cosmologia, dissociando-a das outras vertentes de sua doutrina, sobretudo a metafísica. Na verdade, se examinarmos tanto a física 15], expressa no tratado de mesmo nome, como a cosmologia de Aristóteles [15], tal qual expressa em Os Céus, encontraremos uma combinação extremamente harmoniosa entre pressupostos filosóficos-metafísicos e elementos extraídos de percepções empíricas próximas ao senso comum, cujos argumentos se encontram e se reforçam nas mesmas conclusões. Assim, observamos, por exemplo, nos argumentos em favor do geocentrismo uma fusão da concepção do Universo organizado em termos de lugares naturais e cujo centro caberia ao nosso "mundo"com a realidade empírica de não percebermos em nossa vivência cotidiana qualquer sinal do movimento da Terra.

A partir desses pressupostos e diretrizes, Aristóteles elaborou um modelo cosmológico que, em linhas gerais, prevaleceu até a Era Moderna. Primeiramente, para Aristóteles, a existência do vazio era um contrassenso lógico, na medida em que associaria ao puro não-ser (nada) um atributo positivo, qual seja, o de existir. Dessa forma, sua concepção de Universo não admitia os espaços vazios e, assim, seu Cosmos era completamente preenchido por matéria (pleno).

A partir da conclusão de que o Universo é completamente preenchido por matéria, chega-se à conclusão de que ele é finito, já que, segundo Aristóteles, uma realidade material infinita seria outro absurdo; um infinito atualmente existente não poderia existir [15]. Ora, uma vez finito, Aristóteles atribuiu-lhe a forma tridimensional perfeita por excelência: a forma esférica.

Na visão cosmológica de Aristóteles, a perfeição do Universo também se revela em um ordenamento hierárquico de sua estrutura, onde cada coisa tinha um lugar previamente estabelecido, adequado a sua natureza. A esse respeito, o Filósofo identificava duas formas de natureza radicalmente distintas: uma natureza incorruptível, cuja única mudança possível seria uma mera mudança de posição, chamada por ele de movimento local, e uma natureza corruptível, sujeita a toda sorte de mudanças, até mesmo as mais radicais, que significavam uma transformação de essências, a saber, a geração e a extinção. Para Aristóteles, essa distinção total era devida à matéria de que os objetos eram compostos. Havia, portanto, segundo ele, dois tipos de matéria: uma perfeita e incorruptível, chamada de éter ou quintessência, da qual eram feitos todos os corpos celestes, e uma matéria corruptível, que compunha a realidade terrestre, mais próxima de nós. Incorporando então uma concepção do filósofo présocrático Empédocles de Agrigento, em grande medida já encampada por Platão [16], Aristóteles considerou a matéria do mundo terrestre composta por quatro elementos básicos: terra, água, ar e fogo.

Neste ponto, novamente intervém a ideia de um Cosmos rigidamente organizado. Nele, a disposição da matéria obedeceria a um critério hierárquico de nobreza: os espaços mais externos receberiam a matéria celeste, por ser mais nobre, enquanto a matéria terrestre, corruptível, preencheria a zona central do Universo. A separação entre as duas regiões se daria através de uma superfície esférica, em uma nova manifestação do paradigma das formas perfeitas.

Dentro desse ordenamento hierárquico, os elementos terrestres iriam se dispondo em camadas esféricas concêntricas em torno do centro do Universo, lugar reservado ao elemento terra. Em torno do elemento terra teríamos, pela ordem, os lugares reservados ao elemento água, ao elemento ar e, por último, ao elemento fogo. A Terra, por ser feita prioritariamente do elemento homônimo, teria seu lugar natural reservado no centro do Universo. Isso explicaria o caráter geocêntrico desse Cosmos.

Essa concepção implicaria que cada objeto, conforme sua composição, buscaria espontaneamente ocupar o lugar que lhe era reservado nessa organização hierárquica. Assim, por exemplo, os objetos feitos do elemento terra tenderiam a ocupar um lugar próximo ao centro, onde, não por acaso, se encontra o nosso planeta, e assim cairiam em linha reta em direção a ele. Esta propriedade pela qual o corpo manifestava uma tendência de se aproximar do centro do Universo era chamada de gravidade. Deste modo Aristóteles explicava o fenômeno da queda dos corpos próximos à superfície da Terra. Por sua vez, o elemento fogo tenderia a se afastar deste centro em direção às regiões mais próximas ao mundo celeste. Por isso a chama e a fumaça sobem. Esta tendência inversa de se afastar do centro era denominada por Aristóteles de leveza.

Estabelecidos estes princípios, havia a tratar uma questão fundamental desde sempre: a explicação dos deslocamentos dos corpos celestes. Platão legara à antiguidade grega a ideia de que a forma circular era natural a esses movimentos [16] 17. Esse paradigma da perfeição circular foi absorvido pelo modelo cosmológico aristotélico. Os planetas descreveriam movimentos circulares em torno do centro do Universo, onde se encontrava a Terra. Restava explicar por quê.

Para isso, Aristóteles adotou uma contribuição da astronomia grega anterior. Eudoxo e Cálipo haviam mostrado que seria possível reproduzir matematicamente, de maneira satisfatória, o movimento dos corpos celestes através de uma combinação de movimentos circulares, produzidos como se esses corpos estivessem presos a esferas concêntricas que, ao girarem, arrastariam-nos consigo, fazendo com que realizassem os movimentos desejados. Esse é o chamado "modelo das esferas homocêntricas". No entanto, ao que tudo indica 17 tratava-se apenas de um modelo matemático de descrição do posicionamento dos planetas e estrelas, idealizado por Eudoxo e aprimorado por Cálipo [7]. Aristóteles, contudo, deu a essas esferas uma realidade material e, de um possível artifício matemático-astronômico, elas passaram a elementos reais e estruturais de um modelo cosmológico: na sua visão de Universo, cada um dos planetas estaria ligado a uma esfera centrada na Terra, em rotação permanente e uniforme.

Entretanto, o movimento planetário efetivo resultante de uma estrutura como essa seria um movimento per- 
feitamente circular, o que não correspondia à complexidade das observações astronômicas. Desta maneira, o modelo não poderia ser tão simples. Na verdade, para cada planeta teria de haver um complexo sistema de esferas articuladas - aliás já previstas por Eudoxo - umas encravadas dentro de outras, com o planeta, por sua vez, preso à mais interna delas. Cada uma dessas esferas teria uma rotação independente, respeitado o vínculo da ligação entre elas, como uma espécie de "sistema de engrenagens". O movimento planetário efetivo resultante seria suficientemente complexo para expressar as irregularidades verificadas nos dados experimentais. Para tanto, o número de esferas postuladas evoluiu das trinta e três previstas no modelo de Eudoxo e Cálipo para cinquenta e cinco, propostas por Aristóteles [17. Nesse sistema, portanto, haveria um jogo de esferas para cada planeta conhecido (e assim considerado) até então: Lua, Mercúrio, Vênus, Marte, Sol, Júpiter e Saturno. Finalmente, haveria uma última esfera, limitante do espaço universal, à qual estariam atreladas as estrelas. Por sua vez, a esfera da Lua separaria as regiões terrestre e celeste.

Por sua coerência e capacidade explicativa, essa concepção de Universo prevaleceu, em suas linhas gerais, durante quase vinte séculos, até ser abalada pela proposta heliocêntrica de Nicolau Copérnico.

\section{O modelo astronômico de Ptolomeu}

O Almagesto, obra do astrônomo Claudio Ptolomeu (c.100-c.178 D.C.) cujo título provém de uma tradução árabe, representa a grande apoteose do pensamento astronômico da antiguidade grega, em uma tradição que remonta a Eudoxo e Cálipo, passando por Hiparco, Apolônio e Aristarco.

Eudoxo e Cálipo haviam lançado as bases de uma ciência astronômica fundamentada na modelagem matemática dos dados observacionais e não na mera especulação filosófica 7]. Os astrônomos posteriores trabalharam no aprimoramento da concordância entre essa modelagem matemática e as observações dos movimentos celestes, introduzindo os mecanismos descritivos (de que falaremos mais detalhadamente adiante) dos epiciclos e deferentes, bem como dos excêntricos, e estabelecendo, inclusive, equivalências entre esses mecanismos.

O desenvolvimento de mecanismos de modelagem das órbitas celestes como os epiciclos e os excêntricos trouxe com ele uma crescente dificuldade em se conciliar a descrição astronômica com o sistema cosmológico de Aristóteles, particularmente o imperativo de que os movimentos circulares naturais dos corpos celestes se dessem necessariamente em torno do centro do Universo 17 . Diante da necessidade de enfrentar essa dificuldade, a astronomia ramificou-se então em uma abordagem cada vez mais instrumental e menos preocupada com a realidade física dos mecanismos empregados na descrição dos movimentos celestes e outra, ainda preocupada com a representação das estruturas materiais reais do Universo [7] [17.

Neste cenário se situa a obra de Ptolomeu. Ela abrange as duas vertentes primordiais, embora interligadas: a da descrição matemática, brilhantemente representada pelo Almagesto, e a vertente cosmológica, expressa em uma obra menos conhecida, denominada Hipótese dos Planetas, que permaneceu parcialmente desconhecida do ocidente moderno até o século XIX, quando obteve uma tradução do árabe 17.

A descontar algumas pequenas divergências, por exemplo em relação à natureza da matéria celeste, a visão cosmológica de Ptolomeu é essencialmente baseada na concepção aristotélica do Cosmos finito, pleno e estruturado em termos das esferas cristalinas 17. Entretanto, como forma de descrever corretamente as irregularidades dos movimentos celestes, sua obra astronômica adota uma série de elementos concebidos pelos astrônomos precedentes, sobretudo Hiparco, que obrigaram a adaptações no modelo de esferas de Aristóteles. Destacamos principalmente os mecanismos dos epiciclos-deferentes e dos excêntricos.

O mecanismo dos epiciclos-deferentes consiste na idéia de que os corpos celestes descrevem movimentos circulares (epiciclos) não em torno do centro do Universo, mas em torno de um ponto que, por sua vez, descreve um círculo (deferente) em torno de outro ponto, este último, em princípio, o centro do Universo. O movimento resultante seria a combinação destes dois movimentos circulares. Fazendo-se um ajuste adequado dos raios dos dois círculos, bem como do sentido do movimento epicíclico, era possível obter uma boa concordância com os dados observacionais.

Já o mecanismo dos excêntricos consistia em supor que os corpos celestes descreviam movimentos circulares (excêntricos) em torno de um ponto distinto do centro do Universo.

Mas a causa desta aparência irregular pode ser explicada por duas simples hipóteses. Pois se seu [ dos planetas] movimento é considerado em relação a um círculo no plano da Eclíptica, concêntrico com o Cosmos, de tal modo que nosso olho esteja no centro, então é necessário supor que eles fazem seu movimento regular ou ao longo de círculos não concêntricos com o Cosmos, ou ao longo de círculos concêntricos; mas não simplemente concêntricos com o Cosmos, e sim em círculos carregados por aqueles, chamados de 'epiciclos'.

Pois se, no caso da hipótese da excentricidade

textrm [ figura 1, esquerda ], concebermos o círculo excêntrico $A B C D$, no qual o astro move-se regularmente, com centro em $E$ e diâmetro AED, e o ponto $F$ como se fosse nosso olho, de modo que A se torna o apogeu e $D$ o perigeu; e se, seccionando-se dois arcos iguais, $A B$ e $C D$, ligarmos $B E, B F, C E$ e $C F$, então será evidente que o astro, movendo-se através de cada um dos arcos $A B$ e $C D$ em períodos iguais de tempo, parecerá ter descrito arcos desiguais com centro em $F$. (...) 


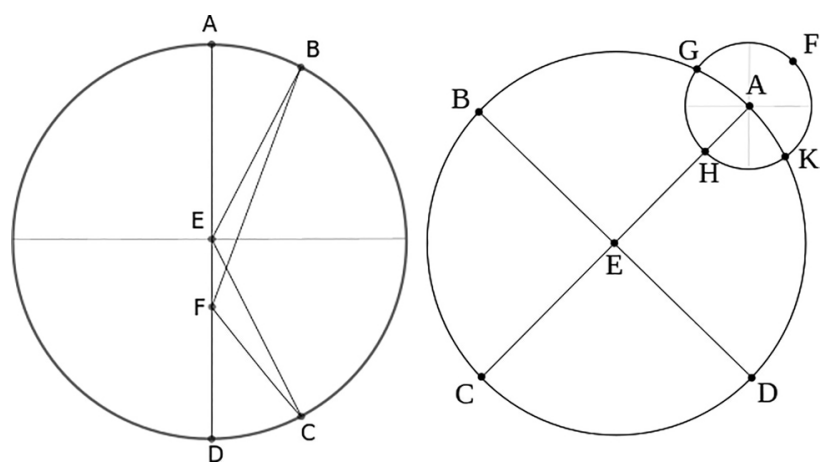

Figura 1: Modelos de Excêntricos e Epiciclos

E se na hipótese do epiciclo considerarmos o círculo $A B C D$ concêntrico com a Eclíptica textrm [ figurd1, direita], centrado em E e com diâmetro AEC, e o epiciclo FGHK, apoiado nele, no qual o astro se move, com seu centro em A, então será imediatamente evidente também que à medida que o epiciclo desloca-se regularmente ao longo do círculo $A B C D$, de A para $B$, por exemplo, e o astro ao longo do epiciclo, este astro parecerá indistintamente estar em A, centro do epiciclo, quando ele estém $F$ ou $H$; porém isso não ocorrerá quando ele estiver em outros pontos. Mas, tendo chegado em $G$, por exemplo, parecerá ter realizado um movimento maior do que o movimento regular pelo arco $A G$; e tendo chegado a $K$, da mesma forma, menos pelo arco $A K[18$, p.86-87] (T.A.).

Cedo foi estabelecida a equivalência entre os dois mecanismos, do ponto de vista da descrição dos posicionamentos planetários - no Almagesto, Ptolomeu atribui esse resultado a Apolônio. Ptolomeu incorporou, na verdade, os dois instrumentos propostos pela tradição da astronomia matemática grega: tanto o sistema de epiciclos-deferentes como o de excêntricos; o centro dos deferentes não coincidia com a Terra. Além disso, Ptolomeu introduziu um elemento a mais em seu sistema astronômico: o centro dos epiciclos não descrevia movimentos circulares com velocidade angular constante, nem em relação à Terra, nem em relação ao centro do deferente, mas sim em relação a um terceiro ponto, chamado equanto, situado sobre a reta que une a Terra e o centro do deferente, de tal modo que esse centro ficaria equidistante daquele ponto e da Terra (Figura(2)).

Mas aplicando-se imediatamente as posições observadas às órbitas construídas a partir da combinação de ambas as hipóteses e continuamente examinando-as em conjunto, verificamos que as coisas não podem prosseguir de forma tão simples:(...)

textrm 2) Os epiciclos não têm seu centro acoplado aos círculos excêntricos cujos centros são aqueles em relação aos quais os centros dos epiciclos giram giram em um movimento

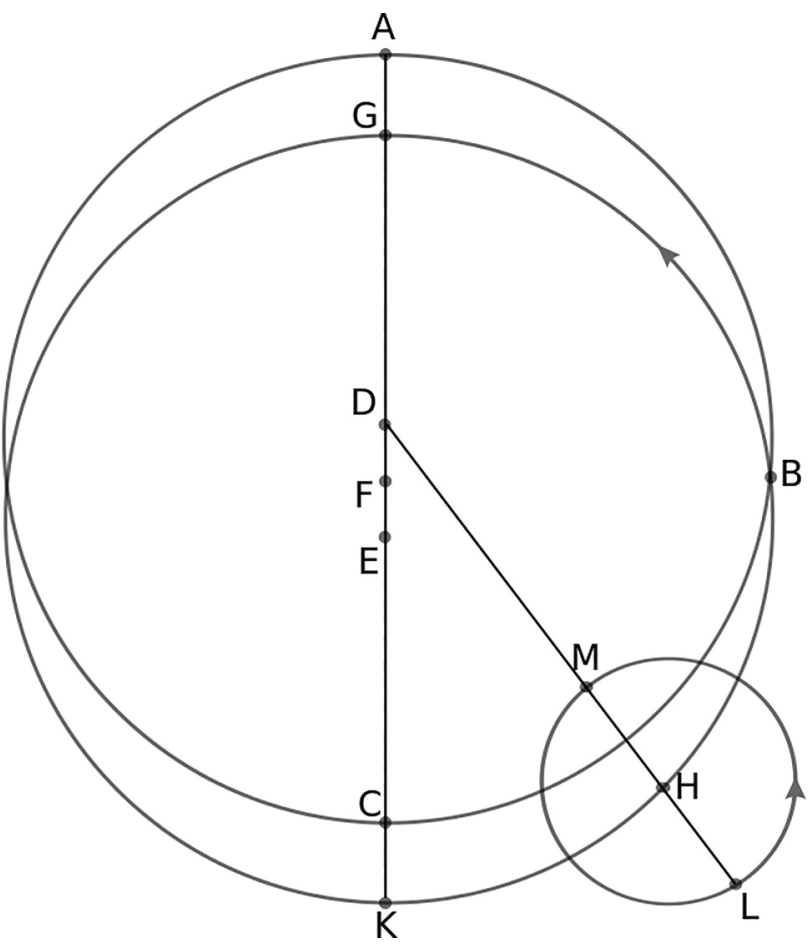

Figura 2: Modelo com Excêntrico, Epiciclo e Equanto

regular oeste-leste e descrevem ângulos iguais em tempos iguais.(...) $E$

textrm (2) os centros dos epiciclos estão acoplados a círculos iguais aos excêntricos que geram a anomalia, mas descritos em torno de outros centros. E esses outros centro $\$$. válidos para todos à exceção de Mercúrio, bissectam as retas entre os centros dos excêntricos que geram a anomalia e o centro da Eclipticd $^{2}[18$, p.291] (T.A.).

E, ainda,

A forma como essas hipóteses recém derivadas seria mais facilmente compreensivel do seguinte modo:

No caso das hipóteses de todos os planetas à exceção de Mercúrio, primeiramente seja concebido o círculo excêntrico $A B C$ em torno do centro $D$, e o diâmetro $A D C$ através de $D$ e o centro da Eclíptica. E sobre esse diâmetro seja $E$ o centro da Eclíptica, o ponto $A$ o apogeu e $C$ o perigeu. E seja DE bissectada em F; e, com F como centro e AD como raio, desenhemos o círculo GHK, igual ao círculo $A B C$. E, com $H$ como centro, desenhe-se o epiciclo $L M$ e a reta $L H M D$.

(...)

E então dizemos que o plano inteiro gira para leste na direção dos signos em torno do centro E, movendo o apogeu e o perigeu de

\footnotetext{
1 equantos
}

${ }^{2}$ T.A. 
um grau em uma centena de anos; que o diâmetro do epiciclo LHM, por sua vez, gira regularmente, em torno do centro D, para leste na direção dos signos(..); e que, ao mesmo tempo, ele faz girar os pontos do epiciclo $L$ e $M$, seu centro $H$ sempre acoplado ao excêntrico GHK, e o próprio astro. E o astro, por sua vez, move-se no epiciclo LM, regularmente em relação ao diâmetro que aponta para o centro $D^{3}[18$, p.292] (T.A.).

A figura (2) mostra um modelo com Excêntrico, Epiciclo e Equanto.

Com esses instrumentos, Ptolomeu conseguiu construir um modelo matemático bastante sastisfatório para a descrição dos movimentos celestes observados. No caso do movimento dos planetas superiores (Saturno, Júpiter e Marte), além de Vênus, o modelo envolve os três elementos, conforme se pode observar da transcrição anterior, retirada do Almagesto.

Para descrever o movimento do Sol, Ptolomeu utilizou, indistintamente, tanto o modelo do excêntrico como o de um epiciclo, baseando-se, para isso, na equivalência já provada entre esses dispositivos.

Segundo Ptolomeu, o movimento do Sol, tal como visto por um observador localizado na Terra, em O, pode ser descrito por um movimento circular ao longo de um excêntrico ABCD, cujo centro dista $e$ de $\mathrm{O}$, conforme mostra a figura (3), ou então por um movimento ao longo de um epiciclo centrado em $\mathrm{E}$ e de raio também igual a $e$, cujo deferente, por sua vez, está centrado na Terra e é percorrido em sentido contrário àquele em que o planeta percorre o epiciclo.

Já o sistema pensado por Ptolomeu para o movimento da Lua já era muito mais complexo.

Imaginemos um observador situado na Terra, representada pelo ponto $\mathrm{O}$, centro do círculo (I)(Figura 4), e suponhamos que a rotação das esferas faça com que esse círculo gire em trono de O no sentido horário. Suponhamos que, ao mesmo tempo, o deferente (II), centrado em $\mathrm{F}$, gire no sentido anti-horário, de tal modo que o ângulo $(\alpha)$ entre o segmento que liga $\mathrm{O}$ ao ponto $\mathrm{A}$, que

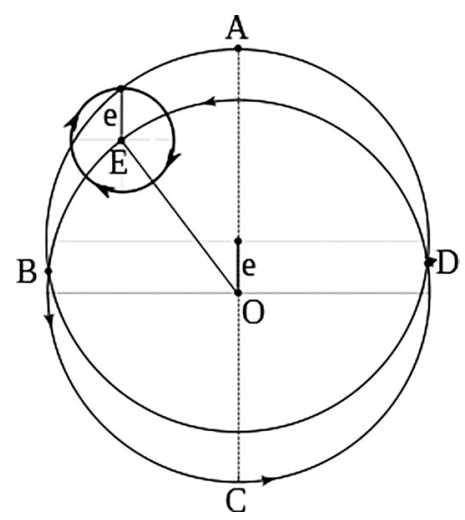

Figura 3: Movimento do Sol segundo Ptolomeu

\footnotetext{
${ }^{3}$ equanto
}

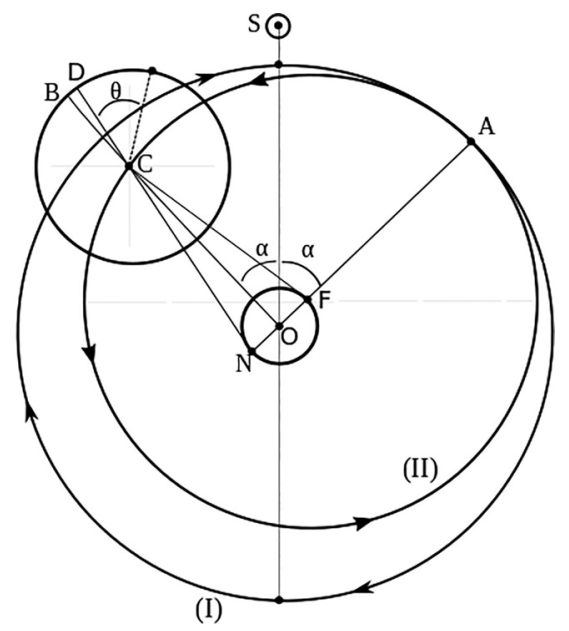

Figura 4: Movimento da Lua visto da Terra segundo Ptolomeu

representa o ponto do deferente mais distante da Terra (apogeu), e a reta que passa pela Terra e pelo Sol é de mesma magnitude que o ângulo entre aquela reta e o segmento OC, onde C é o centro do epiciclo associado à Lua. Pelo movimento da esfera que arrasta o círculo (I), o próprio centro $\mathrm{F}$ do deferente gira em torno de O, descrevendo um círculo de diâmetro PN. A Lua, ela própria, percorre em sentido horário, como dissemos, um epiciclo de centro C. No modelo de Ptolomeu, sua posição é determinada pelo ângulo que o segmento $\mathrm{CP}$ faz com a linha NH.

Em resumo, a partir dessas construções geométricas, Ptolomeu obteve ótima concordância entre a modelagem teórica e as observações astronômicas, conferindo a seu modelo um imenso prestígio científico. No entanto, para aqueles filósofos e pensadores que buscavam não apenas uma modelagem instrumental dos movimentos celestes, mas a descrição realista da estrutura cosmológica, os elementos tomados por Ptolomeu em sua construção, notadamente, os excêntricos e os equantos, implicavam o abandono da idéia esteticamente cativante de esferas materiais girando em torno do centro do Universo e assim realizando uma vocação natural da matéria etérea. Caso se quisesse, como assim parecia ser o caso de Ptolomeu, manter essas estruturas esféricas, era necessário fazêlo de uma maneira bem mais elaborada, imaginando nestas esferas cavidades em forma de camadas circulares excêntricas, onde estariam instalados os planetas. Esse problema foi enfrentado pela astronomia árabe, surgida alguns séculos após.

\section{A Tradição da Astronomia Árabe}

Com a invasão árabe sobre o Império Romano do Oriente, ocorrida no século VII, a herança cultural da civilização grega foi transmitida ao mundo islâmico. Diversas são as obras do pensamento grego que permaneceram durante muito tempo perdidas ou desconhecidas para o Ocidente cristão, mas que foram preservadas em traduções árabes dos manuscritos originais. 
A tradição astronômica brilhantemente sistematizada pela Síntese Matemática de Ptolomeu, agora sob o nome de Almagesto, foi continuada pelos pensadores islâmicos, como Alfraganus, Alhazen, Alpetragius, Averróis e outros. O grande desafio colocado era, como já indicamos, a conciliação entre os princípios fundamentais da cosmologia aristotélica e a complexidade cinemática dos mecanismos propostos por Ptolomeu para descrever os movimentos celestes. Esta conciliação exigia, por exemplo, a existência de camadas esféricas de espessuras irregulares para atender ao mecanismo dos excêntricos, conforme mostra a figura 5

Esta irregularidade - como, aliás, qualquer outro tipo de irregularidade e de violação de princípios metafísicoestéticos do pensamento aristotélico, como, por exemplo, a uniformidade e o caráter estritamente concêntrico de todos os movimentos celestes - despertava em alguns estudiosos desconfiança com relação à veracidade dos mecanismos descritivos astronômicos, a despeito de sua utilidade instrumental. Por conseguinte, também a ciência astronômica árabe se desenvolveu segundo essa tensão subjacente entre a busca de uma interpretação realista das estruturas cosmológicas e uma abordagem instrumental puramente descritiva, desvinculada de preocupações com a realidade dessas descrições.

Nesse sentido, uma importante contribuição foi a de Alhazen, no século X. Em sua obra intitulada em árabe Al-Shukũk e geralmente traduzida no Ocidente como Dúvidas relativas a Ptolomeu, ou, então, Aporias contra Ptolomeu, Alhazen tece diversas críticas a certo artificialismo embutido no modelo de Ptolomeu, sobretudo nas construções geométricas que esse último elaborou para descrever os chamados movimentos de latitude dos pla-

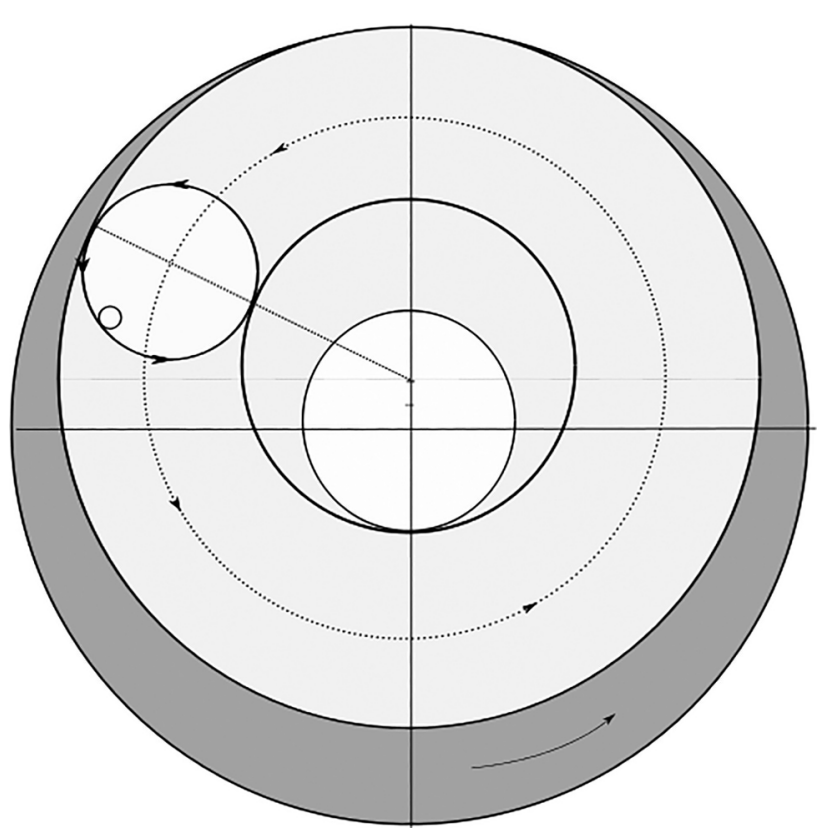

Figura 5: Reprodução da figura contida na obra Sistema para as esferas superiores e para Vênus, de Alhazen, apud W.Hartner, Oriens-Occidens, I.482. netas (localização do planeta segundo sua altura acima da linha do horizonte).

O diâmetro do epiciclo é uma linha imaginária, e linhas imaginárias não possuem movimentos perceptiveis que produzem uma entidade existente no mundo. Da mesma forma, o plano do epiciclo é também um plano imaginário e planos imaginários não produzem movimentos observáveis. E nada se move de um movimento observável, produzindo uma entidade dotada de uma existência no mundo, a não ser corpos que existam [ verdadeiramente ] nesse mundo [19, p.89] (T.A.).

Trata-se de antipatia nítida de uma concepção realista da ciência contra elementos instrumentalistas detectados na construção formulada por Ptolomeu. Essa antipatia se voltou principalmente ao dispositivo do equanto, dando início a uma vertente sólida da astronomia árabe de rejeição desse instrumento.

Na mesma obra citada acima, Alhazen escreve

Ptolomeu reuniu todos os movimentos que podia verificar a partir de suas próprias observações e das de seus predecessores. Ele buscou em seguida uma configuração de corpos realmente existentes que pudesse dar conta de tais movimentos, mas não teve êxito. Ele então recorreu a uma configuração imaginária fundada sobre círculos e linhas imaginárias, ainda que alguns desses movimentos possam existir nos corpos reais. Ele recorreu a esse método unicamente porque não podia encontrar outro. Mas, se imaginarmos uma linha movendo-se de certa maneira segunda nossa própria imaginação, não se segue disso que haja uma linha nos céus semelhante àquela imaginada, movendo-se da mesma forma. Tampouco é verdadeiro que, se umaginarmos um círculo nos céus e, após, um planeta deslocando-se ao longo desse círculo, o planeta [ real] ira realmente se deslocar ao longo desse círculo. Isso posto, a configuração imaginada por Ptolomeu para os cinco planetas é falsa[ hay'a bãtila ] e ele a estabeleceu, sabendo que era falsa, porque não pode encontrar outra. Contudo, os movimentos dos planetas [ reais ] têm uma configuração correta para os corpos existentes [ realmente], que Ptolomeu não capturou, nem pôde representar. Pois não é verdadeiro que possa haver um movimento uniforme, perceptivel e perpétuo que não tenha uma configuração correta em corpos existentes.

Essa passagem é um verdadeiro libelo do realismo epistemológico contra o instrumentalismo "salvador dos fenômenos". Há nela elementos marcantes de uma concepção científica realista, a saber, que existe uma verdade, que essa verdade pode ser capturada pelo conhecimento 
humano e que as descrições científicas devem se apoiar em entes verdadeiramente existentes, que retratem fielmente os fenômenos tal como ocorrem. Concepções que se desviem disso são peremptoriamente falsas. A concepção de Ptolomeu para os movimentos planetários, na medida em que lança mão de elementos que parecem se chocar claramente contra a realidade material, enquadra-se nessa categoria das falsas doutrinas, ainda que dela se possam obter enormes êxitos em se tratando de cálculos e de modelagem matemática. Para Alhazen, existem certamente teorias realistas que forneceriam resultados igualmente bons ou melhores, sem recorrer a traços fantasiosos.

Do ponto de vista técnico, a crítica da astronomia árabe ao sistema ptolomaico consistiu, pois, principalmente, na tentativa de restabelecimento dos princípios da circularidade, da perfeição geométrica e da uniformidade dos movimentos planetários, fragilizados pelos excêntricos e, principalmente, pelo equanto. Essa foi, por exemplo, já no século XIII e XIV, a tônica dos modelos de Mu'yyad al-Urdĩ, Ibn al-Shãtir e Sharaf al-Tusi [19 [10]

A solução que muitos astrônomos árabes deram como alternativa a esses elementos foi a inclusão de epiciclos de epiciclos, de ritmos finamente ajustados. A figura 6 representa o modelo de al-Shãtir para os planetas superiores

Consideremos a Terra $\mathrm{T}$, posicionada no centro de um círculo de raio $\mathrm{R}$. Consideremos o ponto $\mathrm{K}$ - onde antes se situava o centro do deferente de Ptolomeu (não coincidindo com a Terra) - a uma distância $\frac{e}{2}$ de T, e também o ponto $\mathrm{D}$, colinear com os dois primeiros, e situado a uma distância $e$ de T. Nesse ponto, antes se situava o equanto de Ptolomeu. Consideremos, por último, o ponto $\mathrm{Q}$, também colinear com os demais, porém situado abaixo de $\mathrm{T}$, também à distância $e$ dele.

Imaginemos então um segmento de raio $\mathrm{R}$, traçado a partir de $\mathrm{Q}$ e teremos o ponto $\mathrm{H}$, centro de um epiciclo de raio igual a $\frac{3 e}{2}$. Tomemos um segmento $\mathrm{HN}$, congruente com QK, definindo o ponto N, situado sobre o epiciclo, por sua vez, centro de um segundo epiciclo, de raio $\frac{e}{2}$, devidamente ajustado. Consideremos um ponto $\mathrm{O}$ sobre esse segundo epiciclo, de tal modo que o segmento KN faça com NO o mesmo ângulo que faz com KD. O pla-

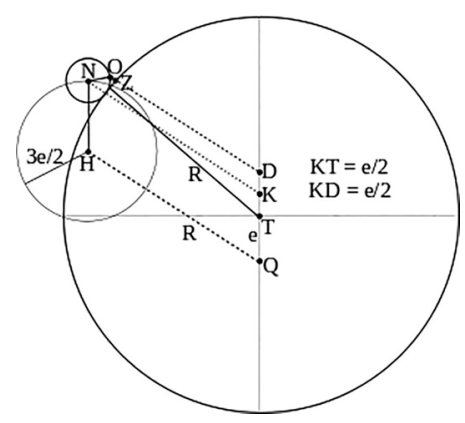

Figura 6: Modelo de al-Shãtir para o movimento dos planetas superiores neta superior se moverá ao longo desse segundo epiciclo, encontrando-se na situação representada, no ponto $\mathrm{O}$.

Al-Shãtir observou que, fazendo todos esses círculos girar em torno de seus próprios centros geométricos. Ajustando-se, além dos raios, os sentidos de rotação dos círculos, bem como os ritmos, al-Shãtir verificou que era possível fazer com que o ponto $\mathrm{O}$ (planeta) se deslocar praticamente sobre o antigo deferente de Ptolomeu (onde estaria o ponto Z), porém a um ritmo constante tomandose como referência o ponto D. Em outras palavras, seria possível reproduzir os resultados de Ptolomeu, inclusive o instrumento do equanto, sem que fosse preciso violar o princípio geométrico e estético de que as esferas - das quais os círculos representam seções - girassem em torno de seus centros geométricos.

\section{Gênese da proposta heliocêntrica de Copérnico}

O ano de 1543 assistiu ao aparecimento de duas obras de notável importância para a história da ciência: um livro de anatomia humana intitulado De humanis corporis fabrica (Da Organização do Corpo Humano), de autoria de Andreas Vesalius e considerada a obra fundadora da ciência anatômica moderna, e um tratado sobre astronomia denominado De Revolutionibus Orbium Coelestium (Das revoluções das esferas celestes"), escrito pelo polonês Nicolau Copérnico.

Embora tenha sido publicado apenas no ano citado, quando seu autor já se encontrava no leito de morte, o De Revolutionibus Orbium Coelestium teve um longo período de gestação. Era a maturação de sua pequena obra manuscrita anterior, de 1510, denominada Commentariolus (Pequeno Comentário), na qual Copérnico já apresentava as ideias mestras de uma nova teoria astronômica, que substituía a Terra pelo Sol como elemento imóvel em torno do qual se organizaria o Universo.

$\mathrm{Na}$ verdade, a publicação de De Revolutionibus veio precedida da publicação - com a anuência de Copérnico -, em 1540, de um livro intitulado Narratio Prima(Primeiro Relato), escrito por seu discípulo Georg Joachim Rheticus, que apresentava as linhas gerais do sistema copernicano já maduro. A Narratio Prima, no entanto, abordava apenas os aspectos qualitativos da organização do sistema, sem entrar nos cálculos e análises quantitativas, diferentemente do que faria logo depois o De Revolutionibus.

Conforme salienta Thomas Kuhn [4], Das Revoluções das esferas celestes é uma obra que ao mesmo tempo se vincula a uma longa tradição astronômica e inaugura uma nova tradição. Nela ainda estão presentes diversos elementos característicos da cosmologia aristotélica que prevaleceu durante vinte séculos, como a finitude do Universo, as esferas homocêntricas 4 os epiciclos e deferentes

${ }^{4}$ Há, no entanto, estudiosos que, apesar da referência aos elementos esféricos no texto, problematizam essa interpretação mais literal. Uma coisa, todavia, parece certa: Copérnico não se manifestou explicitamente a respeito da realidade ou não das esferas homocêntricas da tradição astronômica. 
do sistema ptolomaico, o paradigma dos movimentos celestes circulares e a física das causas formais. Em outras palavras, Copérnico não revolucionou de imediato a visão de mundo antiga, porém os desdobramentos lógicos de sua proposta essencial abalaram de forma fatal os alicerces daquela concepção física e cosmológica.

Embora Copérnico tenha preservado em seu modelo a grande maioria das concepções cosmológicas e astronômicas então vigentes, havia no sistema de Ptolomeu um elemento que lhe era intolerável: a não uniformidade dos movimentos celestes, traduzida no equanto, já criticado por vertentes da astronomia islâmica, conforme vimos. Copérnico era fiel ao paradigma grego da regularidade como expressão da perfeição cósmica; ele acreditava firmemente que os movimentos celestes deveriam se constituir de combinações de movimentos circulares a ritmos rigorosamente uniformes.

Observo que os nossos antepassados assumiram um grande número de orbes celestes principalmente para explicar o movimento aparente dos planetas de acordo com o princípio da regularidade. Pois lhes parecia verdadeiro absurdo que um corpo celeste absolutamente redondo não se movimentasse sempre uniformemente. Mas verificaram que um corpo pode parecer mover-se para qualquer ponto também pela união e combinação de movimentos regulares de várias formas. Cálipo e Eudoxo, que tentaram resolver o problema por meio de círculos concêntricos, não puderam explicar por meio deles o movimento de todos os planetas, não só em relação às aparentes revoluções, mas também pelo fato de que eles ora nos parecem subir para o alto, ora nos parecem descer, o que é incompatível com a concentricidade. Portanto, pareceu mais adequada a opinião de que isso se faz por excêntricos e epiciclos, com o que concorda a maior parte dos estudiosos. Todavia, aquilo que foi transmitido por Ptolomeu $e$ muitos outros aqui e ali sobre isso, embora correspondesse aos dados numéricos, também parecia produzir dúvidas que não eram pequenas. Pois isso não era suficiente a menos que se imaginassem alguns círculos equantes, com os quais os planetas não pareciam mover-se numa velocidade uniforme, nem em seu orbe deferente, nem em torno de seu centro.

Assim, tal especulação não parecia nem bastante absoluta, nem bastante racional. Portanto, como percebi isso, muitas vezes pensei se era possível encontrar um sistema mais racional de círculos dos quais dependesse toda irregularidade aparente, movimentando-se todos eles uniformemente em torno de si [ dos seus centros ], como exige a regra do movimento absoluto [20, p.111-113] (T.A.).

Entretanto, no sistema ptolomaico o equanto era necessário para promover a concordância entre as previsões teóricas e as observações experimentais; a alternativa seria um aumento no número de epiciclos utilizados na descrição dos movimentos planetários, como também haviam chegado a fazer os árabes. Diante disso, eliminá-lo da descrição dos movimentos celestes exigiria uma reformulação mais profunda e estrutural do modelo planetário. Tal motivação levou Copérnico a investigar, com sucesso, a possibilidade de alterar um aspecto central de todo o sistema cosmológico-astronômico: a substituição da Terra pelo Sol como elemento estático do sistema!

Assim feito, Copérnico verificou que algumas características mais específicas dos movimentos dos planetas poderiam ser explicadas com maior naturalidade a partir da hipótese heliostática. Para tanto, era necessário manter o caráter excêntrico do sistema, isto é, as esferas celestes - ou os círculos que correspondem às suas seções - não girariam exatamente em torno do Sol, mas de um ponto próximo a ele, de tal forma que não seria estritamente correto falar em heliocentrismo - tanto quanto não o era falar de geocentrismo na astronomia de Ptolomeu - mas sim de um modelo heliostático.

Tendo enfrentado um problema tão difícil e quase insolúvel, veio-me enfim [ à mente J o modo de resolvê-lo com elementos menos numerosos, mais simples e muito mais convenientes do que os precedentes, se forem admitidas algumas exigências, chamadas axiomas, que seguem nessa ordem

PRIMEIRA EXIGÊECIA

Não existe um centro único de todos os orbes ou esferas celestes.

SEGUNDA EXIGÊECIA

O centro da Terra não é o centro do mundo, mas apenas o da gravidade e do orbe lunar.

TERCEIRA EXIGÊNCIA

Todos os orbes giram em torno do Sol, como se ele estivesse no meio de todos; portanto, o centro do mundo está perto do Sol.

\section{QUINTA EXIGÊENCIA}

Qualquer movimento aparente no firmamento não pertence a ele, mas à Terra. Assim a Terra, com os elementos adjacentes, gira em torno de seus pólos invariáveis em um movimento diário, ficando permanentemente imóveis o firmamento e o último céu.

\section{SEXTA EXIGENCIA}

Qualquer movimento aparente do Sol não é causado por ele mas pela Terra e pelo nosso orbe, com o qual giramos em torno do Sol como qualquer outro planeta. Assim, a Terra é transportada por vários movimentos.

\section{SÉTIMA EXIGÊNCIA}

Os movimentos aparentes de retrogressão e progressão dos errantes não pertence a eles mas à Terra. Apenas o movimento desta é suficiente para explicar muitas irregularidades aparentes no céu. 
Assim, portanto, com essas premissas, tentarei mostrar brevemente como pode ser conservada a uniformidade dos movimentos, de modo sistemático [20, p.113-117] (T.A.).

A hipótese heliocêntrica já havia surgido na antiguidade grega, através, por exemplo, de Aristarco de Samos. Podemos então nos interrogar por que veio a ressurgir apenas na Renascença, pela pena de Copérnico, e não antes? A resposta possível a esta questão envolve analisarmos as condições históricas e o ambiente intelectual do momento em que essa nova concepção germinou.

O chamado Renascimento cultural dos séculos XV e XVI promoveu um imenso interesse por tudo aquilo que dizia respeito à cultura greco-romana clássica. Na esteira desta tendência, diversas correntes de pensamento foram resgatadas e revalorizadas, em detrimento do aristotelismo, cientificamente hegemônico à época. Entre elas estavam o neoplatonismo e o pitagorismo. Essas duas vertentes filosóficas possuíam em comum certos elementos que contribuíram decisivamente para a elaboração de uma nova visão de mundo, entre os quais destacamos a ênfase dada à matemática como linguagem em termos da qual se fundamenta a ordem do Universo. Nesse quesito incluímos a crença no papel essencial das formas geométricas perfeitas e das regularidades matemáticas na constituição do Cosmos. Copérnico estudou, em pleno fervor do Renascimento, nas universidades italianas de Bolonha e Pádua. Na primeira delas foi aluno de Domenico de Novara, um astrônomo conhecido por sua adesão ao neoplatonismo. É possível especular que elementos como esse tenham, por exemplo, levado Copérnico a retomar com redobrada fé o paradigma clássico da uniformidade dos movimentos circulares envolvidos na descrição das órbitas planetárias, rejeitando veementemente o princípio do equanto introduzido por Ptolomeu.

O neoplatonismo e o pitagorismo apresentavam, ademais, outro traço comum bem acentuado: um componente místico, que, entre outras coisas, atribuía ao Sol um papel primordial como símbolo do divino e provedor das condições que possibilitam a vida. Em vista dessa condição singular, era natural que se atribuísse àquele astro uma posição central em nosso Cosmos. A esse respeito, é famosa a citação das palavras do próprio Copérnico, presentes na introdução a seu livro "Das Revoluções":

No centro de tudo, está o Sol entronado. Neste belíssimo templo, poderíamos nós colocar essa luminária noutra posição melhor de onde ela iluminasse tudo ao mesmo tempo? Ele é corretamente chamado a Lâmpada, a Mente, o Governante do Universo; Hermes Trismegisto chama-lhe o Deus Visível, a Electra de Sófocles chama-lhe O que tudo vê. Assim, o Sol senta-se como que num trono real, governando os seus filhos, os planetas que giram a sua volta 21 .

$\mathrm{Na}$ realidade, porém, este estudo da atmosfera intelectual da época permite tão somente uma análise especulativa sobre as motivações filosóficas que podem ter desencadeado a elaboração da nova proposta. Trata-se de uma pergunta das mais profundas, inserida em outra mais ampla, a saber, quais as razões para o abandono racional de paradigmas até então consagrados e ainda não completamente falseados por qualquer observação?

\section{O Sistema Copernicano e as Bases Observacionais da Astronomia}

Passemos agora à análise mais técnica, porém qualitativa, das modificações introduzidas por Copérnico e de como elas foram capazes de dar resposta aos principais problemas relacionados às descrições dos movimentos celestes.

A observação astronômica realizada ao longo de milênios havia proporcionado uma série de informações a respeito da cinemática celeste. $\mathrm{O}$ desafio dos sucessivos modelos astronômicos era, como dissemos, descrever com precisão esses elementos observacionais, como, por exemplo, o movimento aparente diário das estrelas ao longo do céu, o movimento anual do Sol ao longo do horizonte e os movimentos irregulares dos diversos planetas.

No que se refere ao movimento noturno das estrelas e constelações, o dado experimental evidenciava que estes movimentos eram absolutamente coletivos, isto é, eram realizados em conjunto pelas estrelas, sem que as distâncias entre elas se alterassem. Na antiguidade este fato foi determinante para a ideia de que as estrelas se dispusessem sobre uma esfera rígida, a girar em torno do nosso planeta. Contudo, ele poderia ser igualmente explicado pela rotação da própria Terra (e os observadores nela situados), mantendo-se fixa a estrutura das estrelas.

No entanto, as observações das variações noturnas dos posicionamentos das estrelas criavam uma dificuldade para a ideia do movimento de translação (na nossa linguagem atual) anual do nosso planeta em torno do Sol. De fato, verificava-se que, considerando-se duas referências diametralmente opostas na esfera estelar, enquanto uma delas despontava no horizonte a outra se punha do outro lado. A conclusão tradicional era de que a linha do horizonte terrestre coincidia com o diâmetro da esfera estelar, ou seja, a Terra se situava no centro desta esfera. Entretanto, se agora, com Copérnico, a Terra se movia, mesmo que ela em algum momento estivesse acidentalmente no centro da esfera estelar, lá não permaneceria, de forma que esse tipo de comportamento de pontos de referência diametralmente opostos na abóbada celeste não se repetiria o ano todo.

Copérnico respondeu a esta aparente contradição ressaltando que ela estaria subordinada à precisão das observações que lhe servem de base, qual seja, a do mencionado posicionamento dos pontos de referência diametralmente opostos. De fato, a afirmação de que quando um deles desponta no horizonte o outro se põe não é absoluta, no sentido de que está sujeita a uma incerteza observacional. Ora, segundo Copérnico, mesmo que a Terra não fosse o centro da esfera estelar, mas desde que permanecesse suficientemente próxima a ele, não seria possível detectar a falta de simultaneidade entre o nascente e o poente de 
pontos diametralmente opostos, dentro da incerteza das observações a olho nu. A figura 7 mostra a situação.

Consideremos a Terra representada por uma pequena esfera descrevendo um círculo em torno do centro da esfera estelar e um plano tangente a ela, Terra, cuja interseção com a esfera das estrelas constitui a linha do horizonte. Se a grandeza do raio do círculo terrestre for significativo em comparação com o raio da esfera das estrelas, então, ao considerarmos dois pontos diametralmente opostos da abóbada celeste, eles não estarão simultaneamente sobre a linha do horizonte. Todavia, se o raio da órbita terrestre for pequeno em comparação com o raio da esfera estelar, então a diferença em relação à simultaneidade perfeita estaria contida dentro da margem de incerteza observacional.

Seguindo esta linha de raciocínio, Copérnico era obrigado a aumentar em várias ordens de grandeza a estimativa clássica do raio da esfera das estrelas, tendo em vista a estimativa já existente da distância entre a Terra e o Sol, que corresponderia ao raio do círculo orbital terrestre. Adotando uma incerteza observacional de $0,1^{0}$, pequena em se tratando de observações a olho nu, Copérnico redimensionou o raio da esfera estelar como 1.000 vezes a distância da Terra ao Sol, ou seja, 1.528 .000 vezes o raio do planeta Terra. Este aumento do raio estimado do Universo abriu margem para a reformulação da imagem do Cosmos em direção à ideia de um espaço infinito 22 .

Outro ponto importante relacionado ao movimento aparente das estrelas, tal como percebido por um observador terrestre, ele próprio em movimento junto com o Planeta, consiste na chamada paralaxe estelar.

A figura 8 seguinte mostra a natureza do fenômeno.

À medida que a Terra vai se movendo em torno do Sol, em seu ciclo anual, a angulação dos raios que provêm de qualquer estrela em relação ao plano da órbita vai mudando, de modo que um observador terrestre veria esta estrela em posições angulares diferentes o ano inteiro, descrevendo nos céus um círculo de período igual ao ano terrestre. Ora, este efeito não havia sido jamais observado até a época de Copérnico - na verdade, só foi observado no século XIX. Entretanto, novamente, caso a distância

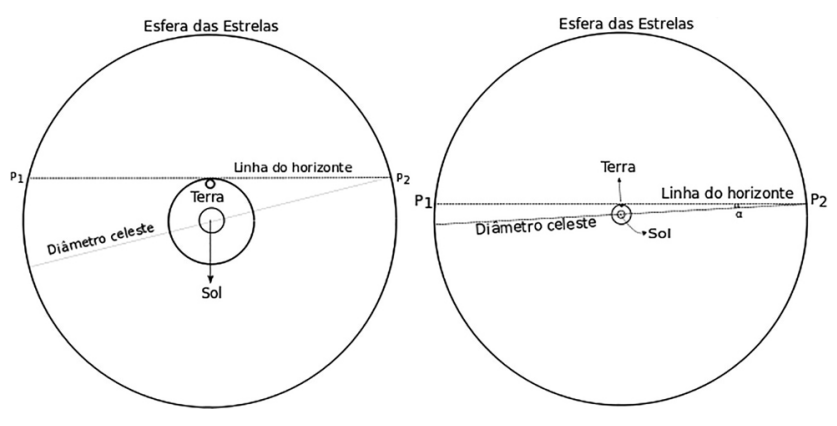

Figura 7: A figura mostra como a linha do horizonte terrestre difere do diâmetro da esfera estelar quando o raio da órbita da Terra é significativo em comparação com o diâmetro daquela esfera, e como as duas linhas aproximadamente coincidem quando o raio da órbita terrestre vai se tornando muito pequeno em comparação com aquele diâmetro. da Terra à estrela fosse muito maior do que o raio da órbita terrestre em torno do Sol, o ângulo de paralaxe $\theta$ seria muito pequeno e quase imperceptível ao nível experimental. Essa consideração, assim como a anterior, fazia com que o Universo pensado por Copérnico fosse então, forçosamente, de dimensões muito maiores do que até então imaginado.

No que tange ao movimento aparente do Sol visto pela Terra, a análise copernicana é simples. Na verdade, como a Terra orbita em torno do Sol, no sentido de oeste para leste, para o observador terrestre é o Sol que gira em torno da Terra, em sentido oposto, como mostra a figura 9

Já o movimento da Lua era descrito no modelo copernicano por um sistema de dois epiciclos, tal como já haviam feito astrônomos árabes: o primeiro deles descrevendo um movimento uniforme em torno de um ponto do deferente, enquanto o segundo, que tinha a Lua em um de seus pontos, descrevia também um movimento uniforme em torno de um ponto do primeiro epiciclo, conforme mostra a figura (10). Através de um ajuste adequado dos parâmetros, no caso, as velocidades dos movimentos e os raios dos epiciclos, Copérnico conseguia a reprodução precisa dos posicionamentos lunares.

Prosseguindo na análise dos movimentos celestiais tal como vistos por observadores na Terra em movimento, Copérnico trata da descrição dos movimentos dos planetas.

É um fato sabido desde a antiguidade que os planetas, vistos da Terra, realizam movimentos alternadamente progressivos e retrógrados, isto é, movimentam-se de oeste para leste ao longo do céu, porém parando, às vezes,

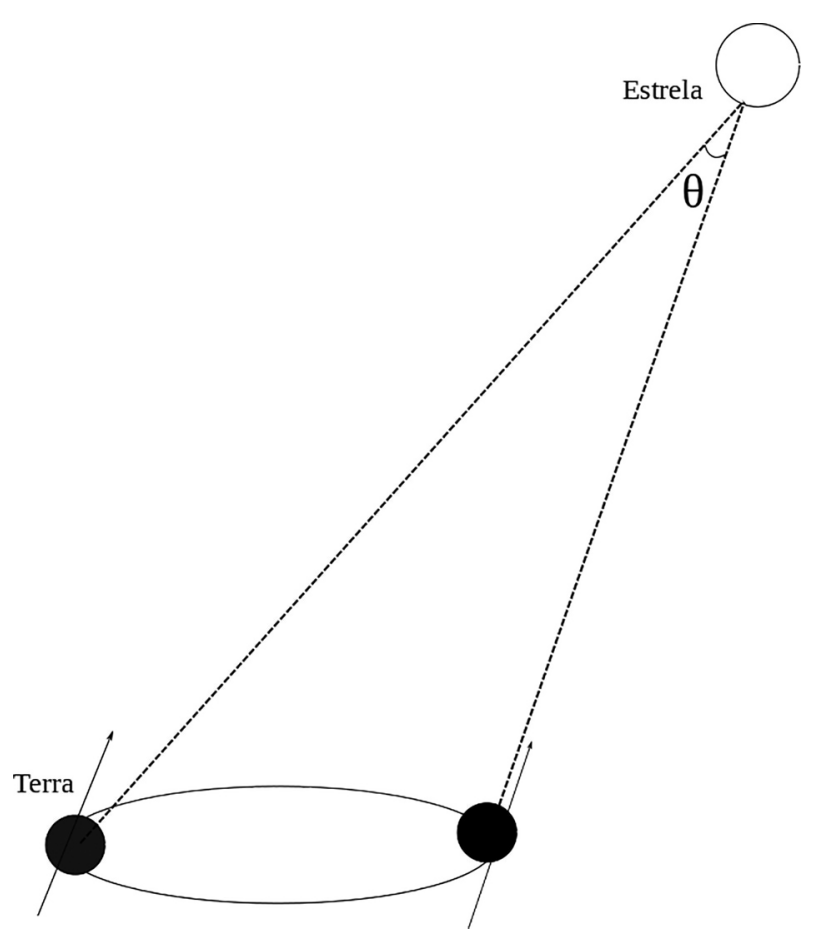

Figura 8: A figura mostra a diferença angular (paralaxe) da posição de uma estrela tal como vista da Terra. 


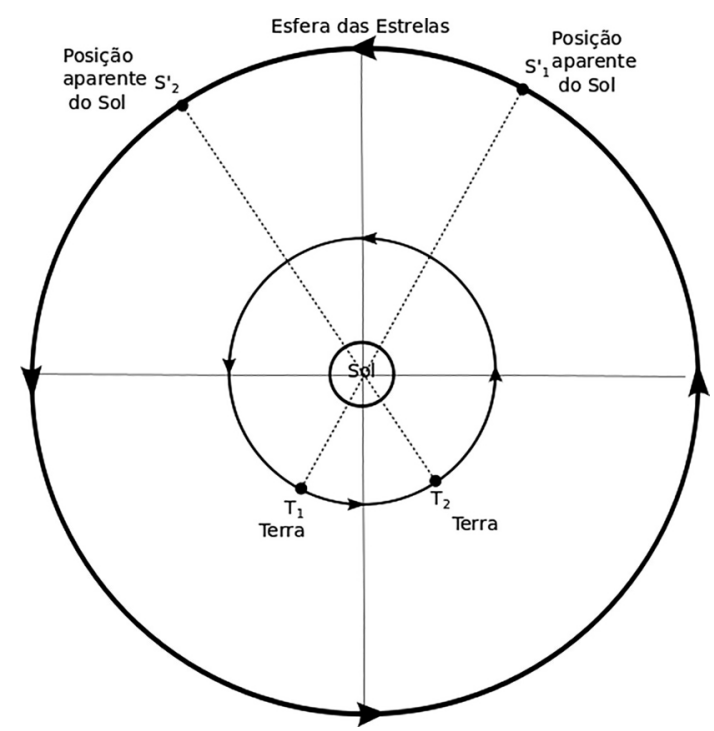

Figura 9: A figura mostra o movimento aparente do Sol sobre a esfera das estrelas, conforme visto pelo observador terrestre em movimento.

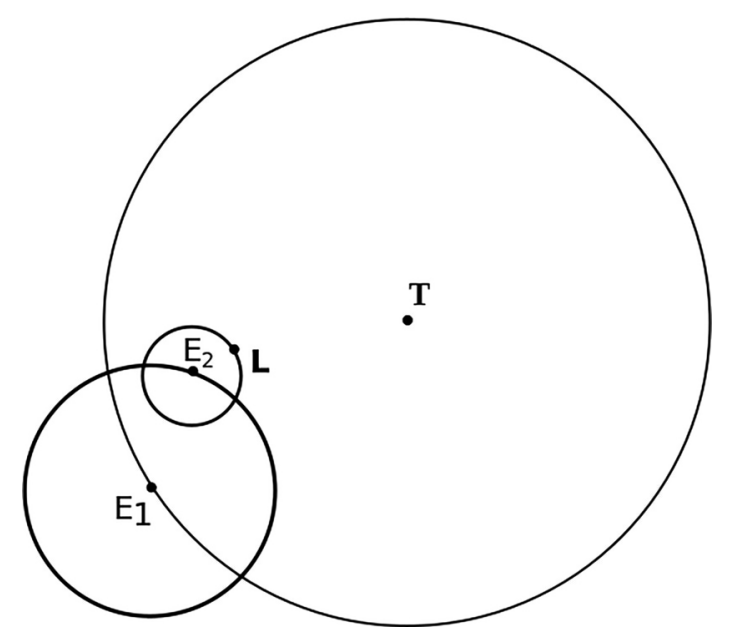

Figura 10: A figura mostra o sistema de dois epiciclos para descrição do movimento da Lua em torno da Terra(T). O primeiro epiciclo tem centro em $E_{1}$, enquanto o segundo, o qual está a Lua(L), tem centro em $E_{2}$.

e retrocedendo durante um tempo, para depois voltar ao movimento normal. Esta movimentação complexa era descrita no modelo de Ptolomeu, conforme vimos, por uma combinação conveniente de deferentes e epiciclos.

Copérnico conseguiu descrever esses movimentos planetários em termos de um movimento aparente resultante de observarmos os planetas a partir de um referencial móvel (Terra).

A figura 11 mostra uma diagrama representando simultaneamente as órbitas da Terra e de um planeta em torno do sol, bem como a esfera das estrelas. Como a referência de posicionamento dos planetas são as estrelas, interessa-nos estudar o que seria a projeção da posição dos planetas sobre a esfera estelar.

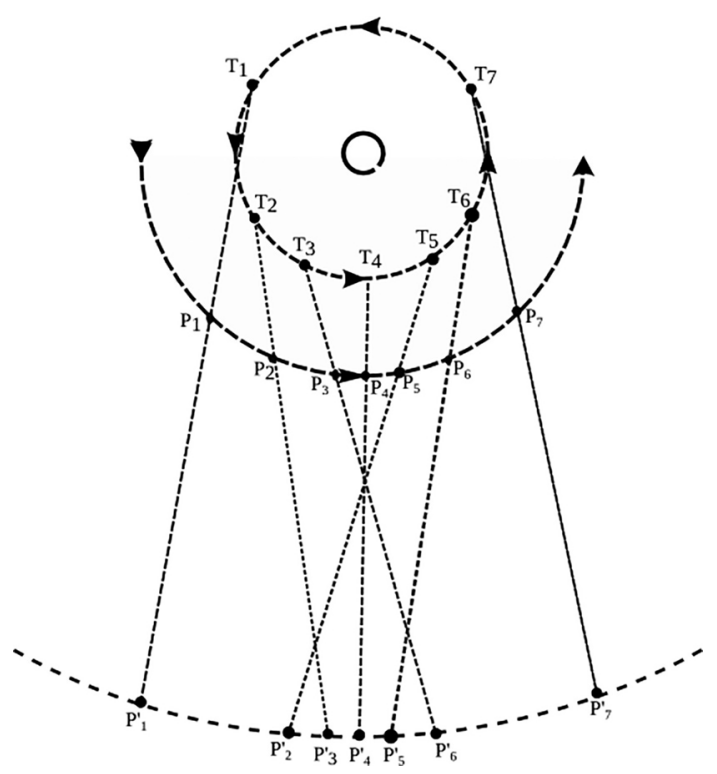

Figura 11: Movimentos aparentes dos planetas, conforme vistos da Terra.

Com este objetivo, considermos sete posições sucessivas da Terra $\left(T_{1}, T_{2}, T_{3}, T_{4}, T_{5}, T_{6}\right.$ e $\left.T_{7}\right)$ e de outro planeta $\left(P_{1}, P_{2}, P_{3}, P_{4}, P_{5}, P_{6}\right.$ e $\left.P_{7}\right)$ sobre suas respectivas órbitas em torno do Sol, a intervalos de tempo regulares. Considerando a velocidade angular do planeta menor do que a da Terra, na medida em que as órbitas mais externas sejam percorridas mais lentamente, fazemos a projeção das pontos $P_{i}$ na esfera das estrelas $\left(P_{1}^{\prime}, P_{2}^{\prime}, P_{3}^{\prime}\right.$, $P_{4}^{\prime}, P_{5}^{\prime}, P_{6}^{\prime}$ e $\left.P_{7}^{\prime}\right)$. Observamos que há uma alternância de progresso e retrocesso no movimento das projeções $P_{i}^{\prime}$, explicando qualitativamente os fenômenos observados.

Como dissemos, o mecanismo explica qualitativamente de forma extremamente simples a ocorrência do movimento regressivo dos planetas. Por este aspecto qualitativo, a solução de Copérnico se apresentava como mais elegante do que a de Ptolomeu. Contudo, quando passou à descrição quantitativa dos dados observados, Copérnico foi obrigado a tornar seu sistema bem mais complexo, recuperando os mecanismos dos excêntricos e dos epiciclos, necessitando de um total de mais de trinta círculos para a descrição das irregularidades dos movimentos planetários. Lembremos que toda essa complexidade resulta de um fato fundamental, somente elucidado no século seguinte por Kepler: tentava-se descrever por meio de combinações circulares órbitas, na verdade, elípticas.

Com efeito, na versão incipiente, apresentada no Commentariolus, Copérnico conseguiu reproduzir os movimentos planetários recorrendo a um esquema com dois epiciclos por planeta. Já na versão publicada na Narratio Prima de Rheticus, Copérnico havia conseguido eliminar, ao menos para os cinco outros planetas além da Terra, o epiciclo adicional. O movimento dos planetas superiores (Saturno, Júpiter e Marte) foi representado por um esquema formado por um epiciclo e um deferente, com ritmos de movimento devidamente ajustados. Já os planetas inferiores (Vênus e Mercúrio) eram representa- 
dos por um epiciclo de raio maior do que o deferente. $\mathrm{O}$ centro desse deferente, por sua vez, não coincidia nem com o Sol nem com o centro do deferente da Terra.

Além disso, meu muito sábio Schöner, você vê que aqui, no caso da Lua, nós nos liberamos do equanto, e isso graças a uma teoria que, além do mais, concorda com a experiência e todas as observações. Do mesmo modo, no caso dos outros planetas, meu mestre suprimiu os equantos atribuindo a cada um dos três planetas superiores um único epiciclo $e$ um excêntrico, tais que um e outro se movem uniformemente em trono de seus próprios centros e que o planeta, sobre o epiciclo, tem o mesmo período de revolução que o excêntrico. Em se tratando de Vênus e Mercúrio, ele lhes atribui um excêntrico de excêntrico. Quanto ao fato de que os planetas aparecem todos os anos, direitos, estacionários, retrógrados, próximos e afastados da Terra, etc.., isso pode advir, meu mestre o demonstra, de um movimento regular do globo terrestre(...) Esse movimento é tal que o Sol ocupa o meio do Universo, enquanto a Terra, em lugar do Sol, gira sobre o excêntrico que meu mestre decidiu chamar grande orbe [23, p.122] (T.A.).

A figura 12 ilustra esse sistema.

Antes de tudo, devemos observar que, apesar de termos dito que o modelo copernicano explicava características gerais e específicas dos movimentos de forma mais natural, em termos de complexidade a concepção heliocêntrica não apresentava uma melhora visível em comparação com o sistema geocêntrico. Com efeito, em ambos os cenários temos combinações semelhantes de epiciclos e deferentes excêntricos; apenas, com Copérnico elimina-se o equanto, necessitando-se, porém, ao menos no caso lunar e no caso terrestre, da inserção de um epiciclo adicional. Como disse Charles Couston Gillespie

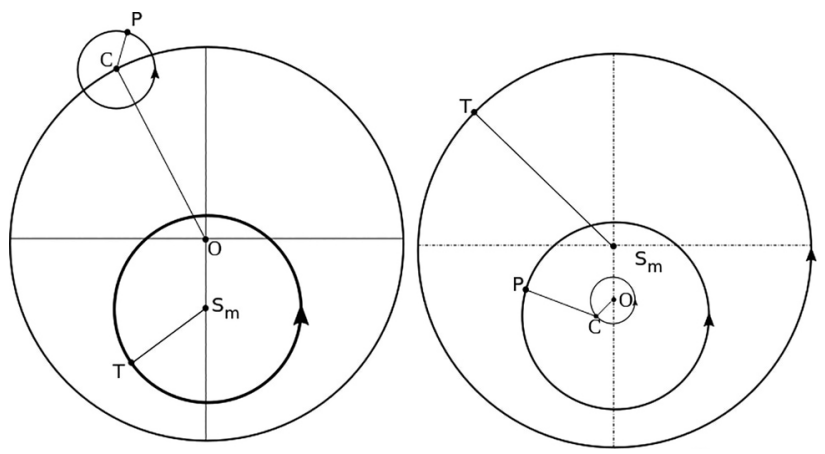

Figura 12: A figura 12 mostra a estrutura de movimento de um planeta superior: o planeta $\mathrm{P}$ se move sobre o epiciclo centrado no ponto $C$ do deferente, por sua vez centrado em $O$. Percebe-se que este não coincide com o centro do deferente da Terra. Já a figura $12 \mathrm{p}$ mostra o sistema dos planetas inferiores.
O fundamento era o círculo, a figura perfeita. E, mais do que a economia, é o princípio da circularidade que expressa a essência de sua visão de mundo.(...) A superioridade do sistema copernicano, portanto, era mais conceitual do que real Sua justificação se situa no futuro, quando os dados se aperfeiçoariam, não no passado, de onde veio sua inspiração [24, p.24] (T.A.).

O sistema proposto por Copérnico explicava também outra observação experimental: os planetas inferiores, Mercúrio e Vênus, sempre permanecem próximos ao Sol. O sistema ptolomaico justificava esta característica fazendo uma vinculação ad hoc entre o centro do epiciclo destes planetas e as posições da Terra e do Sol. Já o sistema copernicano explicava naturalmente este traço dos movimentos planetários. Para tanto, consideremos a figura 13

Nela vemos que, para um planeta "inferior", a situação de máximo afastamento do planeta em relação ao Sol, do ponto de vista terrestre, ocorre quando a reta que une a Terra ao planeta é tangente à órbita desse planeta em torno do Sol, produzindo ainda assim um ângulo agudo de observação.

O Sistema de Copérnico também é capaz de estimar o raio das órbitas dos diversos planetas em torno do Sol, constituindo isso para Copérnico, como discutiremos adiante, um grande mérito epistêmico relacionado à unidade sistêmica do modelo.

De fato, consideremos novamente a figura 13 , mostrando um planeta inferior, o Sol e a Terra, na situação em que esse planeta está, do ponto de vista terrestre, o mais afastado possível do Sol. Já mencionamos que isto ocorre quando a reta que une a Terra ao planeta é tangente a sua órbita, de tal modo que faz um ângulo de $90^{\circ}$ com o raio orbital definido pelo ponto de tangência. Temos, portanto, um triângulo retângulo, cujo um dos ângulos, $\alpha$, corresponde ao ângulo entre as linhas de observação do planeta e do Sol, que provém, pois, dos dados

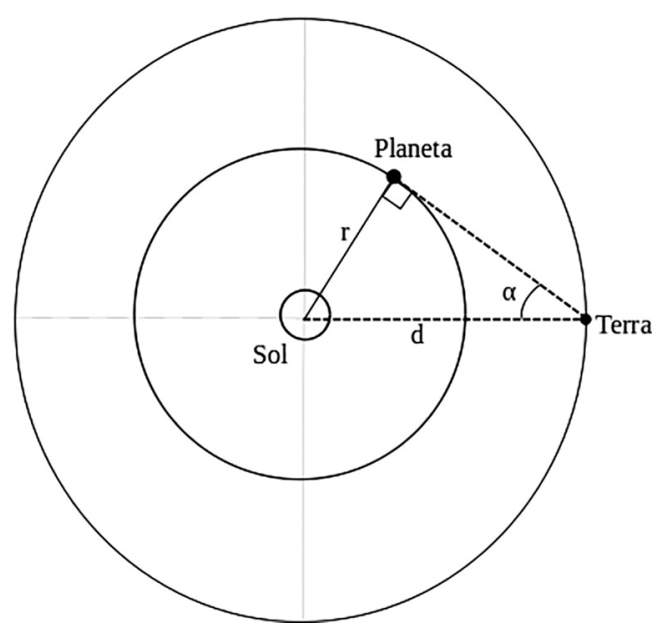

Figura 13: A figura mostra um planeta "inferior"na situação em que, do ponto de vista terrestre, está mais afastado do Sol. 
observacionais. Por conseguinte, podemos conhecer os três ângulos do triângulo, além de um dos lados, qual seja, a distância $d$ entre a Terra e o Sol e, desta forma, também todos os outros. Podemos, assim, determinar o raio da órbita do planeta em questão, ou seja, sua distância até o Sol.

Uma técnica semelhante pode ser usada para o caso de planetas superiores.

Com efeito, consideremos agora as órbitas de um planeta deste tipo e da Terra em torno do Sol (figura 14).

Existe um instante em que o Sol $S$, a Terra $T$ e o planeta $P$ estão alinhados. Esta posição é identificável, pois o planeta e o Sol estarão diametralmente opostos à Terra. Como a Terra tem uma velocidade angular maior do que a do planeta (por este ser mais externo), então, decerto, haverá um instante, que pode ser determinado observacionalmente, em que a linha que une a Terra (em $T^{\prime}$ ) a ele $\left(P^{\prime}\right)$ fará um ângulo reto com o raio da órbita terrestre correspondente àquela posição. $\mathrm{O}$ ângulo TST' pode ser determinado, uma vez que tem com o ângulo total de $360^{\circ}$ a mesma relação que o número de dias decorridos entre as duas posições analisadas tem com o período terrestre de 365 dias. Como esses dois instantes são identificáveis pela observação, então o ângulo em questão também o será. Por sua vez, o ângulo PSP' também pode ser determinado do mesmo modo, uma vez que se conhece o período orbital do planeta. Sendo assim, o ângulo T'SP', $\alpha$, pode ser calculado pela subtração dos dois anteriores. Novamente, conhecidos os dois ângulos do triângulo retângulo e um dos lados (raio da órbita terrestre), $d$, podemos determinar os outros dois, um dos quais é o raio da órbita do planeta superior. Por conseguinte, no esquema copernicano, ao contrário do ptolomaico, as distâncias dos planetas ao Sol são determinadas diretamente das observações.

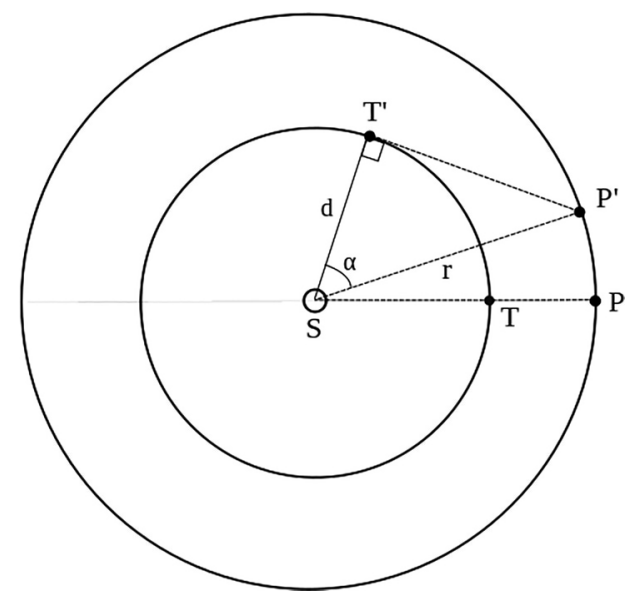

Figura 14: Através de cálculo geométrico simples é possível determinar a grandeza da órbita planetária.

\section{Os fundamentos epistemológicos da teoria copernicana}

Na introdução a seu livro Das Revoluções, Copérnico escreveu uma dedicatória em forma de carta ao Papa Paulo III. Nela, embora ressalvando o caráter ousado e de certo modo perturbador de sua hipótese heliocêntrica, ele apresenta argumentos em defesa de sua admissibilidade. Esses argumentos expõem com alguma clareza a natureza da sua concepção epistemológica sobre a doutrina por ele proposta.

A tradição astronômica havia evoluído apoiando-se fortemente na ideia da modelagem descritiva dos movimentos celestes - esforço esse traduzido na expressão "salvar os fenômenos", empregada pela primeira vez, segundo consta, pelo filósofo grego Simplício 25$]^{5}$ - sem a preocupação correspondente com a validade físico-cosmológica das estruturas matemáticas em termos das quais se efetuava essa modelagem. Como vimos, à medida que os modelos incorporavam novos elementos e, por conseguinte, se tornavam geometricamente mais e mais complexos, sua justificação cosmológica tornava-se cada vez mais problemática.

Nesse sentido, segundo Copérnico, a tradição da astronomia de base ptolomaica ecleticamente lançava mão de modelos distintos para a descrição dos movimentos dos diferentes planetas, sobretudo conforme fossem "inferiores"ou "superiores". Uma vez que a preocupação essencial era a correção matemático-astronômica da descrição de viés instrumentalista das posições ocupadas, o ecletismo dos elementos utilizados nos diferentes casos podia obedecer somente a um critério de eficiência,

Então, estabelecendo os movimentos lunar e solar, bem como o das outras cinco estrelas errantes, eles não empregam os mesmos princípios, hipóteses ou demonstrações para as revoluções e movimentos aparentes. Pois alguns fazem uso de círculos homocêntricos apenas, outros de círculos excêntricos e epiciclos, por meios dos quais, contudo, não conseguem aquilo que buscam. Pois, embora aqueles que confiaram nos círculos homocêntricos tenham mostrado que diversos movimentos distintos podem ser compostos de tais círculos, entretanto não foram capazes de estabelecer nada que corresponda plenamente aos fenômenos. Mas mesmo se esses que imaginaram os excêntricos pareceram capazes de, para a maior parte, computar numericamente os movimentos aparentes por aqueles meios, eles entretanto admitiram diversas coisas que parecem contradizer os princípios primeiros da regularidade do movimento. [21, p.507]

Os modelos astronômicos careciam, pois, de unidade sistêmica e essa era, segundo Copérnico, uma das principais virtudes de sua proposta: empregar uma concepção

\footnotetext{
${ }_{5}^{5}$ Alguns estudiosos atribuem o conceito traduzido por essa expressão a Platão
} 
global única na determinação dos movimentos de todos os corpos celestes a partir da ideia fundamental de que eram movimentos aparentes (paraláticos) decorrentes, em parte, da condição móvel em que nós próprios, observadores, nos encontramos, acompanhando nosso planeta.

Segundo Copérnico, a adoção da hipótese do movimento da Terra permitia não só a uniformização dos modelos descritivos dos movimentos de todos os demais planetas como também a determinação das distâncias planetárias ao Sol, que, nos modelos ptolomaicos, são parâmetros livres. Essas distâncias são determinadas a partir dos ângulos de observação dos planetas a partir da Terra em posições distintas e da distância entre a Terra e o Sol, como vimos na seção anterior. Deste modo, essa distância define uma escala de referência para as distâncias ao Sol de todos os demais planetas.

Mais do que isso, é o movimento da Terra na teoria copernicana que impõe ao modelo essa articulação entre as distâncias dos planetas ao Sol. Para Copérnico, este ponto é de fundamental importância: essa capacidade do modelo de fornecer os parâmetros em que se organiza o Universo, aliada, por certo, à uniformidade dos esquemas descritivos para os diversos corpos (epiciclos, deferentes, excêntricos,...), representa para ele um triunfo científico e uma grande superioridade epistêmica sobre modelos alternativos. De fato, para Copérnico, essa unidade conceitual e essa capacidade preditiva conferiam a seu modelo uma enorme vantagem e verossimilhança, que apontavam para o caminho da verdade. Como diz Szczeciniarz, "a coerência da teoria deve ser a expressão da coerência do mundo"[26, p.50] (T.A.) e, ainda, demonstrar "a unidade do Todo como todo é para Copérnico uma prova de que sua teoria é um retrato vivo da realidade" $[26$, p.49] (T.A.):

\section{(...) se os movimentos das outras estrelas} errantes forem correlacionadas ao movimento circular da Terra, e se os movimentos forem computados de acordo com a revolução de cada planeta, não apenas todos os fenômenos se seguem disso mas também essa correlação atrela tão fortemente a ordem e a magnitude de todos os planetas e de suas esferas ou círculos orbitais, bem como dos próprios Céus, que nada poderá ser deslocado em qualquer parte sem desestruturar as partes restantes e o Universo como um todo. [21, p.508] (T.A.).

Ao que tudo indica, sua convicção no novo modelo nascia dessa concisão e dessa elegância intelectual, muito mais do que de uma precisão ou eficácia superior.

Mas mesmo se aqueles que conceberam círculos excêntricos pareceram ser capazes de calcular numericamente a maior parte dos movimentos aparentes por esses meios, eles admitiram, entretanto, muita coisa que parece contradizer os princípios de regularidade dos movimentos. Sobretudo, eles não foram capazes de descobrir ou inferir os pontos principais, isto é, a forma do mundo e a exata comensurabilidade entre suas partes. (...)Isso não teria acontecido a eles se houvessem seguido princípios corretos. Pois, se as hipóteses que seguiram não fossem falsas, tudo aquilo que delas decorresse seria, sem dúvida alguma, confirmado. [21, p.507] (T.A.).

Por fim, é importante dizer que, ainda do ponto de vista astronômico, o modelo de Copérnico tinha o mérito de proporcionar essa maior unidade à construção teórica sem, com isso, sacrificar sua abrangência epistêmica com a perda de problemas, isto é, não havia questões estritamente astronômicas que fossem esclarecidas pelo concepção ptolomaica e que tivessem deixado de sê-lo, adequadamente, pela teoria copernicana.

Entretanto, se talvez não podemos dizer que no modelo de Copérnico tenha havido perda de problemas no sentido epistêmico, podemos dizer que ele acarretou a geração de novos problemas, relacionados à ciência dos fenômenos terrestres. De fato, a proposição do movimento da Terra se chocava frontalmente com a falta de evidências empíricas desse movimento. A solução desse problema exigiu a elaboração de toda uma nova ciência do movimento, uma nova física.

\section{As repercussões da proposta heliocêntrica de Copérnico}

Embora a proposta de Copérnico alterasse apenas um elemento fundamental da Cosmologia aristotélica o geocentrismo - ela abalou de forma irreversível a sustentabilidade daquela concepção como um todo. Com efeito, de maneira quase paradoxal, o caráter integrado e sistêmico do pensamento aristotélico, em grande medida responsável pela sua enorme aceitação ao longo de tantos séculos, foi ao mesmo tempo a razão de sua fragilidade, uma vez que a eliminação de uma de suas peças retirava do todo a coerência e a organicidade que eram sua máxima virtude. Se a Terra não ocupava mais uma posição central no Universo, como justificar a existência de um mundo (sublunar) próprio, singularizado pela sua constituição a partir de uma matéria diferenciada e pela submissão a leis distintas daquelas verificadas no restante do Cosmos? Em outras palavras, como justificar a existência de uma dicotomia metafísica radical no Cosmos, tal como assumida por Aristóteles, a distinguir o entorno de um corpo celeste que, no mais, se colocava em pé de igualdade com os demais? A proposta copernicana suscitava naturalmente questões como essa, conduzindo, por um desdobramento lógico, ao desafio à visão de mundo aristotélica.

Frente a este conflito iminente, o copernicanismo necessitaria de argumentos bastante eloquentes a seu favor. Contudo, como também foi ressaltado por Thomas Kuhn [4], o novo modelo astronômico proposto por Copérnico não era mais preciso do que o de Ptolomeu, dado que este último sofreu ao longo do tempo sucessivos ajustes para torná-lo bem concordante com os dados observacionais. Além disso, diversos elementos da descrição dos movimentos planetários que os tornavam menos 
arbitrários ( ad hoc) ou mais naturalmente explicáveis em termos da nova hipótese heliostática estavam em certa medida obscurecidos pela complexidade dos detalhes técnicos astronômicos, acessíveis a poucos leitores. Em contrapartida, a atribuição de movimento à Terra chocava-se frontalmente com a percepção humana mais imediata e com a tradição religiosa, apoiada nos textos sagrados, assim como com a tradição acadêmica e filosófica. Sendo assim, torna-se fácil compreender a resistência que lhe foi oferecida e o fato de sua aceitação ter sido apenas gradual.

De qualquer forma, o processo de transformação radical do pensamento do homem desencadeado pela proposta heliocêntrica de Copérnico gerou um enfrentamento entre duas visões de mundo, sobretudo entre o novo pensamento científico e o tradicionalismo religioso e intelectual, este último encarnado no aristotelismo dominante nos meios acadêmicos. Desses dois embates, o primeiro teve, de longe, lances mais dramáticos e abalou profundamente a liderança intelectual da Igreja no mundo ocidental.

Nesse sentido, muito se conjectura sobre uma possível demora de Copérnico em publicar seu livro Das Revoluções. As especulações recaem sobretudo sobre um seu possível temor em relação a um clima de intolerância religiosa desencadeado pela reforma protestante e suas repercussões políticas.

De fato, em 1517 Martinho Lutero lançou seu manifesto de noventa e cinco teses que deu a partida ao movimento de Reforma Protestante. Imediatamente outros reformadores seguiram seus passos e logo toda a Europa estava em uma situação de conflagração político-religiosa que conduziu a um século de guerras devastadoras. Certamente não era uma época propícia para o desenvolvimento de ideias heterodoxas de qualquer natureza. $\mathrm{O}$ editor final do Revolutionibus, o teólogo protestante Andreas Osiander, possivelmente temendo a repercussão negativa da inovação contida no livro, nele incluiu, à revelia do autor, um prefácio ressalvando que o modelo proposto não deveria ser entendido como uma interpretação estritamente realista do Universo, mas como uma hipótese matemática, isto é, como um método matemático de descrição, novamente instrumental, dos movimentos astronômicos.

De fato, a preocupação de Copérnico com a repercussão política de sua obra parece atestada ao menos por uma carta escrita a ele por Osiander em 20 de abril de 1541, na qual o teólogo luterano diz:

Eu tenho sempre tido o sentimento de que as hipóteses não são artigos de fé, mas uma base de cálculo, de tal sorte que mesmo que sejam falsas isso não tem importância, desde que reproduzam exatamente os movimentos aparentes.(...) Pareceria, assim, desejável que você falasse um pouco dessa questão na sua introdução, pois dessa maneira você neutralizaria os peripatéticos e os teólogos, cuja oposição você teme. apud [20, p.44] (T.A.).

De todo modo, a hierarquia católica, mesmo assombrada pelo inimigo da rebelião, de início não se posicionou doutrinariamente de forma institucional a respeito da controvérsia copernicana. O Concílio de Trento (15451563), convocado para combater o furacão da Reforma, foi omisso em relação ao debate astronômico. Curiosamente, as primeiras resistências explícitas à inovação copernicana partiram das hostes reformistas.

Com efeito, alguns líderes protestantes, se desafiadores do ponto de vista político-teológico, por outro lado abraçaram uma exegese bíblica deveras conservadora sob o aspecto científico, apoiada na literalidade do texto sagrado. O próprio Lutero fez uma referência não muito apreciativa a respeito de Copérnico como o "companheiro que deseja subverter toda a astronomia"e concluiu: "Mesmo sobre essas coisas que estão sendo lançadas na desordem eu acredito nas Sagradas Escrituras" 27.

Nesse sentido também se manifestou Calvino. Em um sermão pregado provavelmente no ano de 1556, falando a respeito da Primeira Epístola de São Paulo aos Coríntios 28:

Vemos que ensinamento devemos recolher desta passagem: o de não disfarçar nem o bem, nem o mal, porém caminhar na simplicidade e na verdade. Quando vemos alguma coisa boa e louvável, confessemos que assim é; e não sejamos semelhantes a esses fantásticos que possuem um espírito de amargura e contradição, para criticar tudo e perverter a ordem da natureza. Veremos alguns tão frenéticos, não somente na religião, mas para em tudo mostrar que possuem uma natureza monstruosa, que afirmam que o Sol não se mexe e que é a Terra que se move e gira. Quando virmos tais espíritos, é preciso dizer que o diabo os possuiu, e que Deus nos oferece-lhes como espelho, para fazer com que permaneçamos em seu Temor. [28, p.162] (T.A.).

Já Philip Melanchton, principal discípulo de Lutero, manteve em relação às novas propostas astronômicas uma posição mais ambígua. Além de teólogo, Melanchton era sobretudo um humanista, relativamente instruído a respeito de questões científicas. Assim, se por um lado ele se manifestou explicitamente de acordo com a cosmologia e a física de Aristóteles, descartando a nova doutrina de Copérnico como uma reedição dos erros do sistema heliocêntrico de Aristarco de Samos, há elementos em sua biografia que apontam uma visão mais benevolente em relação ao astrônomo polonês 28. Em particular, Melanchton parece ter, se não estimulado, ao menos permitido o interesse acadêmico pelas novas doutrinas astronômicas na Universidade de Wittenberg, centro de estudos luterano por ele conduzido. Na verdade, constituiu-se em Wittenberg um círculo de astrônomos estudiosos do modelo copernicano, dentre os quais se destacaram o próprio Rheticus (a quem Copérnico havia confiado a edição de sua obra máxima, mas que, no último momento, impossibilitado de realizar a tarefa, cedera lugar a Osiander) e Erasmus Reinhold. Se o primeiro, conforme vimos, foi um adepto fervoroso do copernicanismo, 
o segundo adotou um tratamento eminemente instrumentalista, transformando, segundo Robert Westman, de "um livro de teorias e princípios em um conjunto de regras e preceitos"[29, p.159] (T.A.), a partir das quais elaborou uma importante tabela de dados astronômicos denominada Tabelas Prutênicas.

Contudo, se a hierarquia da Igreja Católica não respondeu imediatamente à proposta científica de Copérnico, quando fez, o fez de maneira definitiva e, para muitos, desastrosa para o prestígio do cristianismo no debate intelectual da sociedade moderna.

De fato, em 1609, Galileu, já completamente convencido da verdade do sistema copernicano, realizou observações astronômicas com o auxílio de um telescópio, através das quais fez uma série de constatações que reforçavam sua própria crença sobre a validade do heliocentrismo: a irregularidade da superfície lunar - reforçada pela irregularidade da superfície solar, manifesta nas manchas solares, observadas pouco tempo depois - apontava a violação do paradigma da perfeição geométrica do mundo celeste em oposição à corruptibilidade do mundo terrestre; a observação dos satélites de Júpiter mais uma vez retirava da Terra uma distinção fundamental na estrutura do Cosmos - outros planetas também constituíam centros orbitais para corpos celestes; a existência dos hoje conhecidos anéis de Saturno, que se afiguraram a ele, Galileu, como luas daquele planeta.

Todas as observações anteriores são evidências indiretas contra o modelo ptolomaico, na medida em que se contrapõem diretamente ao sistema de pensamento aristotélico, que constitui o alicerce teórico do primeiro. Diferentemente ocorre com a observação por Galileu das fases exibidas pelo planeta Vênus, em analogia com o que ocorre com a Lua.

De fato, com o auxílio do telescópio pode-se observar que a imagem de Vênus apresenta variações cíclicas ao longo do ano, tanto de tamanho quanto de porcentagem de superfície iluminada. A sequência de fases tal como se exibia era um comportamento dificilmente compatível com o sistema geocêntrico. Contudo, conforme salienta Kuhn, o sistema de Tycho Brahe, em que os planetas giravam em torno do Sol e este, por sua vez, girava em torno da Terra, também era compatível com essas evidências empíricas.

(...) o sistema de Tycho, pelo menos, fornece uma boa explicação, assim como o de Copérnico, para as fases observadas de Vênus e para a distância até esse planeta. [4, p.238].

Essas descobertas - à exceção da observacão das manchas solares, posterior em alguns poucos anos, foram apresentadas no livro O Mensageiro das Estrelas, de 1610. Com toda a sua controvérsia, a obra rendeu a Galileu uma significativa notoriedade, que lhe valeu inclusive, durante uma visita a Roma em 1611, uma recepção honrosa pelo Papa Paulo V e pelo Collegio Romano, uma instituição católica de estudos de astronomia e matemática [30].

Entretanto, a atmosfera se anuviou rapidamente. Em 1616, a polêmica copernicana, amplificada pela pena de
Galileu, despertou o zelo doutrinário da Inquisição. O caso caiu sob a análise do Cardeal Roberto Belarmino, um dos maiores teólogos do catolicismo. Novamente, o debate se deu entre a visão de Galileu, sustentando veementemente o realismo do modelo copernicano, contra Belarmino, para quem o heliocentrismo representaria apenas um modelo matemático instrumentalmente interessante para a descrição dos fenômenos astronômicos, sem, no entanto, conotações realistas.

A posição de Belarmino está muito bem exposta nessa carta a Paolo Antonio Foscarini, de 12 de abril de 1615:

Digo que se houvesse uma verdadeira demonstração de que o Sol está no centro do mundo e a Terra no terceiro céu, e que o Sol não circunda a Terra, mas a Terra circunda o Sol, então seria preciso ir com muita consideração e explicar as Escrituras que parecem contrárias, e antes dizer que não as entendemos do que dizer que é falso o que se demonstra. Mas não acreditarei que haja tal demonstração, enquanto não me for mostrado. Não é o mesmo demonstrar que, supondo que o Sol esteja no centro e a Terra no céu se salvam as aparências, e demonstrar que na verdade o Sol esteja no centro e a Terra no céu; pois a primeira demonstração creio que possa haver, mas da segunda tenha grandissima dúvida, e em caso de dúvida não se deve deixar a Escritura Sagrada, exposta pelos Santos Padres. [30, p.163].

Já a posição de Galileu é apresentada em uma carta a Piero Dini, de maio de 1615:

(...) com a esperança, pelo menos, de mostrar quanto afeto nutro pela Santa Igreja, e o zelo que alimento de que não aconteça, pela influência de gente malvada e que nada entende dessas matérias, que se tome alguma resolução nada boa, qual seja, declarar que Copérnico não considerasse verdadeira a mobilidade da Terra por ser um fato natural, mas que apenas, como astrônomo, a tomasse como uma hipótese acomodada para explicar as aparências, embora em si mesma falsa, e que por isso se admitisse usá-la como tal, proibindo acreditá-la como verdadeira textrm (...) [30, p.191].

O desfecho desse embate se deu com uma medida de força: em 1616, a Inquisição condenou a posição de Galileu, além do livro Revolutionibus, com a sua inclusão no ‘index' de obras proibidas aos cristãos por seu conteúdo teológico contrário (na avaliação da época) ao Cristianismo. Galileu foi formalmente advertido pelo Santo Ofício de que não defendesse a tese copernicana como uma descrição real da constituição do Universo. Foi justamente a violação a essa advertência que foi alegada pela Inquisição posteriormente, já em 1633, para a condenação de Galileu à prisão, a pretexto de que o seu 
descumprimento estava caracterizado pela defesa implícita do modelo copernicano na obra Diálogo sobre os dois máximos sistemas do mundo, por ele publicada em 1632 .

No entanto, Annibale Fantoli, que estudou cuidadosamente o assunto, escreve que, mesmo após a condenação da teoria copernicana pela Inquisição em 1616,

$A$ atitude diferente [ da Inquisição ] em relação aos livros de Copérnico e de De Zuñiga, por um lado, e ao de Foscarini, por outro, deriva do fato que, feitas algumas modificações e cancelamentos, os dois primeiros podiam continuar a ser lidos sem problemas e até com proveito (em particular, o De Revolutionibus acabava assim reduzido a uma pura hipótese matemática, exatamente na linha do prefácio de Osiander, ao passo que no Comentário de De Zuñiga bastava eliminar a passagem em que era sustentada a compatibilidade do copernicanismo com a Escritura). (...) Quanto às correções que se deviam fazer ao De Revolutionibus, por meio de ulteriores documentos citados por Brandmüller e Greipl [31, p.148-151], deduz-se que o encargo de estudar a questão foi devolvido a Francesco Ingoli. (...) Ainda que adversário de Copérnico, Ingoli estava pessoalmente convencido da grande utilidade do De Revolutionibus no plano matemático. [30, p.209].

No entanto, apesar dessa ofensiva desencadeada pela polêmica envolvendo Galileu, a concepção copernicana avançou de forma irresistível. No momento em que o Revolutionibus foi proibido, Kepler já havia publicado boa parte de sua obra astronômica, apresentando uma teoria descritiva dos movimentos planetários segundo o princípio heliocêntrico proposto por Copérnico.

Finalmente, as evidências empíricas do movimento terrestre foram se estabelecendo. Em 1838, Friedrich Bessel fez as primeiras verificações bem sucedidas da paralaxe estelar vinculada à translação da Terra. Por outro lado, em 1851, Jean Bernard Léon Foucault realizou seu famoso experimento de pêndulo, cujo resultado atesta o movimento de rotação do Planeta. Outras manifestações da rotação da Terra surgem através de efeitos não inerciais, centrífugos e de Coriolis, nos problemas de balística, na circulação dos ventos e correntes marinhas, na erosão das margens dos rios e diversos outros fenômenos terrestres.

\section{Conclusão}

A Revolução Copernicana constituiu um dos eventos fundantes da cultura moderna. A substituição da Terra pelo Sol como elemento imóvel em torno do qual se organiza o Universo promoveu uma transformação completa do visão do Homem sobre si e sobre o Mundo. Essa transformação implicou o abandono de uma concepção cosmológica milenarmente estabelecida, de amplas conotações simbólicas. Como resultado, entrou em choque com sistemas de pensamento, valores e crenças bastante consolidados, em uma época politicamente muitíssimo conturbada, na qual o Cristianismo se via assolado pela mais dramática divisão cismática de sua história.

Procuramos entender, então, que virtudes e fragilidades tinha essa concepção científica de tão profundas implicações sociológicas e antropológicas para enfrentar e dobrar as fortes resistências que lhe foram apostas, direta e indiretamente subvertendo todo o arcabouço intelectual em que se baseava a visão de mundo à época. Vimos que o modelo astronômico de Ptolomeu constituiu uma grande síntese da astronomia grega, obtendo êxito na incorporação de diversos elementos técnicos introduzidos por seus antecessores, como os excêntricos e os sistemas deferentes-epiciclos, bem como na introdução de novos, como os equantos, proporcionando assim, uma descrição bastante exata dos movimentos celestes. Vimos também que o desenvolvimento posterior da ciência astronômica, sobretudo árabe, se deu, em larga medida, impulsionada por um conflito fundamental entre o emprego exitoso desses dispositivos geométricos na modelagem dos movimentos planetários e a observância dos princípios metafísicos e estéticos da visão cosmológica de Aristóteles, sobre a qual se alicerçou toda a ciência durante séculos. Em outros termos, muito mais do que de uma busca por aprimoramento dos resultados quantitativos oferecidos pela modelagem teórica, a dialética do desenvolvimento da ciência astronômica se deu a partir da tensão entre as virtudes descritivas de uma abordagem matemática de viés que hoje poderíamos chamar de instrumentalista e as ressalvas realistas em relação à validade de mecanismos, como os equantos e os excêntricos, que violavam frontalmente princípios básicos do pensamento científico e filosófico da época, .

Essa tensão atingiu um primeiro auge, quando Copérnico, incapaz de aceitar o emprego do mecanismo dos equantos para a descrição do movimento dos planetas, o substituiu pela troca de papéis entre a Terra e o Sol e estabelece seu modelo heliostático. Vimos que, no geral, a força intelectual dessa proposta não poderia se ancorar em um progresso evidente em termos de precisão ou simplicidade técnica, se comparada aos modelos de matriz ptolomaica.

Analisamos então, brevemente, os aspectos epistemológicos da concepção copernicana. Vimos que a unidade sistêmica, a partir da qual as diversos elementos do conjunto, como, por exemplo, as distâncias dos Planetas ao Sol, eram deriváveis das hipóteses básicas, constituía para Copérnico o maior mérito epistêmico de sua concepção e sintoma claro de sua veracidade. De fato, o grande apelo do novo modelo astronômico parecia residir mais nessa economia de pressupostos e na maior naturalidade das descrições astronômicas que daí resultava do que em qualquer outro fator de convencimento. Mencionamos, também, que o modelo copernicano tinha ainda a vantagem dessa maior unidade sistêmica sem que, para tanto, tivesse de pagar o preço da perda de problemas epistêmi- 
cos, deixando sem explicação fenômenos que antes eram esclarecidos pelos modelos de base geocêntrica.

Por outro lado, se não havia perda de explicações para antigos problemas, o modelo copernicano gerava suas próprias questões, em especial: como admitir o movimento da Terra se não observamos seus efeitos em nosso cotidiano? A solução dessa controvérsia exigiu a elaboração de uma nova Física e de uma nova ciência: a Ciência Moderna.

Por fim, analisamos como se deu a receptividade a essa transformação protagonizada pela proposta heliocêntrica de Copérnico. Demos especial ênfase às interações da nova visão científica com o universo religioso. Vimos aí que a sugestão, talvez desonesta em relação aos propósitos do autor, de uma interpretação instrumentalista do modelo copernicano foi lançada como forma de preservar a astronomia nascente do embate frontal com o tradicionalismo religioso. Entretanto, quando Galileu,adepto fervoroso da nova visão científica, não cedeu em sua visão realista de que a doutrina copernicana traduzia a verdade da organização do Universo, o conflito tomou formas brutais. Seu desfecho foi, no plano objetivo, a condenação de livro de Copérnico à inclusão na lista das obras proibidas aos cristãos por conter proposições contrárias à fé e de Galileu, dezessete anos mais tarde, à prisão domiciliar. No plano mais subjetivo, esse processo significou, a nosso juízo, um terrível abalo na prestígio intelectual da Igreja Católica perante o pensamento científico moderno.

\section{Referências}

[1] A. Koyré, Études Newtoniennes (Gallimard, Paris, 1968).

[2] A. Koyré, Études Galiléennes (Herman, Paris, 1966).

[3] E. Burtt, As Bases Metafísicas da Ciência Moderna (Editora UnB, Brasília, 1983).

[4] T.S. Kuhn, A Revolução Copernicana (Edições 70, Lisboa, 1990).

[5] E. Rosen, Copernicus and his successors (The Hambledon Press, London, 1995).

[6] A. Koyré, The Astronomical Revolution (Dover, New York, 1992).

[7] J.L.E. Dreyer, A History of Astronomy from Thales to Kepler (Dover, New York, 1953).

[8] R.A. Martins, Commentariolus - Pequeno comentário de Nicolau Copérnico sobre suas próprias hipóteses acerca dos movimentos celestes. Introdução, Tradução e Notas (Livraria da Física, São Paulo, 2003).

[9] F.R.R. Évora, A Revolução Copernicano-galileana (Editora Unicamp, Campinas, 1993).

[10] H.A. Barros-Pereira, Revista Brasileira de Ensino de Física 33, 4603 (2011).

[11] D.P.A. Pilling e P.M.C. Dias, Revista Brasileira de Ensino de Física 29, 613 (2007).

[12] B.C. van Fraassen, A Imagem Científica (Editora Unesp, São Paulo, 2006).

[13] N. Abbagnano, Dicionário de Filosofia (Martins Fontes, São Paulo, 2014).

[14] E. Mach, Die Mechanik in ihrer Entwicklung (F. A. Brockhaus AG, Leipzig, 1933).
[15] Aristoteles, Oeuvres Complètes (Flammarion, Paris, 2014).

[16] Platão, em: Platon, Oeuvres Complétes (Gallimard, Paris, 1943).

[17] M.P. Lerner, Le Monde des Sphères I (Les Belles Lettres, Paris, 1996).

[18] C. Ptolomeu, Almagest (Encyclopaedia Britannica Inc., Chicago, 1952).

[19] G. Saliba, em: Histoire des Sciences Arabes - 1, editado por R. Rashedi (Éditions du Seuil, Paris, 1997).

[20] N. Copernicus, Commentariolus (Livraria da Física, São Paulo, 2003).

[21] N. Copernicus, On the Revolutions of the Heavenly Spheres (Encyclopaedia Britannica Inc., Chicago, 1952).

[22] H. Hugonnard-Roche, E. Rosen e J.P.Verdet, Introducion à l'Astronomie de Copernic (Librairie Scientifique et Technique Albert Blanchard, Paris, 1975).

[23] G.J. Rheticus, em: Introducion à l'Astronomie de Copernic editado por H. Hugonnard-Roche, E. Rosen e J.P. Verdet (Librairie Scientifique et Technique Albert Blanchard, Paris, 1975).

[24] C.C. Gillispie, The Edge of Objectivity - an essay in the history of scientific ideas (Princeton University Press, Princeton, 1960).

[25] J. Ferrater Mora, Dicionário de Filosofia (Martins Fontes, São Paulo, 1996).

[26] J.J. Szczeciniarz, Copernic et la Révolution Copernicienne (Flammarion, Paris, 1998).

[27] M.A. Gillespie, The Theological Origins of Modernity (The University of Chicago Press, Chicago, 2009).

[28] R. Stauffer, em: Avant et Aprés Copernic - La répresentation de l'Univers et ses conséquences épistémologiques (Librairie Scientifique et Technique Albert Blanchard, Paris, 1975).

[29] R.S. Westman, The Copernican Question - Progonostication, Skepticism and Celestial Order (University of California Press, Los Angeles, 2011).

[30] A. Fantoli, Galileu - pelo copernicanismo e pela Igreja (Ed. Loyola, São Paulo, 2008).

[31] W. Brandmüller e E. Greipl, Galilei e la Chiesa (Leo S. Olchski, Firenze, 1992). 